\title{
Innate immunity and resistance to tolerogenesis in allotransplantation
}

\section{Gilles Benichou 1,2, Makoto Tonsho ${ }^{1,2}$, Georges Tocco ${ }^{1,2}$, Ognjenka Nadazdin ${ }^{1,2}$ and Joren C. Madsen ${ }^{1,2 *}$}

${ }^{1}$ Transplant Research Center, Massachusetts General Hospital and Harvard Medical School, Boston, MA, USA

2 Department of Surgery, Massachusetts General Hospital and Harvard Medical School, Boston, MA, USA

\section{Edited by:}

Xian Chang Li, Brigham and Women's Hospital, USA

Reviewed by:

Joan Stein-Streilein, Schepens Eye Research Institute, USA

Zhibin Chen, University of Miami Miller School of Medicine, USA

\section{*Correspondence:}

Joren C. Madsen, Massachusetts General Hospital, Cox 654, 55 Fruit Street, Boston, MA 02114, USA.

e-mail: jcmadsen@partners.org
The development of immunosuppressive drugs to control adaptive immune responses has led to the success of transplantation as a therapy for end-stage organ failure. However, these agents are largely ineffective in suppressing components of the innate immune system. This distinction has gained in clinical significance as mounting evidence now indicates that innate immune responses play important roles in the acute and chronic rejection of whole organ allografts. For instance, whereas clinical interest in natural killer (NK) cells was once largely confined to the field of bone marrow transplantation, recent findings suggest that these cells can also participate in the acute rejection of cardiac allografts and prevent tolerance induction. Stimulation of Toll-like receptors (TLRs), another important component of innate immunity, by endogenous ligands released in response to ischemia/reperfusion is now known to cause an inflammatory milieu favorable to graft rejection and abrogation of tolerance. Emerging data suggest that activation of complement is linked to acute rejection and interferes with tolerance. In summary, the conventional wisdom that the innate immune system is of little importance in whole organ transplantation is no longer tenable. The addition of strategies that target TLRs, NK cells, complement, and other components of the innate immune system will be necessary to eventually achieve long-term tolerance to human allograft recipients.

Keywords: innate immunity, tolerance, transplantation, allografts, rejection

\section{INTRODUCTION}

Colossal advances over the past decades with the use of immunosuppressive drugs have significantly enhanced the early survival of allogeneic organs and tissues in clinical transplantation (Cecka, 1998; Opelz et al., 1999; Opelz and Dohler, 2008a,b). Nevertheless, longer term success rates remain disappointing due to treatment-related complications and chronic allograft rejection, a process characterized by perivascular inflammation, tissue fibrosis, and luminal occlusion of graft blood vessels (Hayry et al., 1993; Hosenpud et al., 1997; Russell et al., 1997; Kean et al., 2006). This stresses the need for the development of selective immunetherapies designed to achieve transplantation tolerance defined as indefinite graft survival in the absence of immunosuppression and graft vasculopathy (Billingham et al., 1953; Owen et al., 1954). While tolerance to some solid organ allografts has been accomplished in several experimental rodent models, consistent establishment of tolerance in patients still remains an elusive goal. It is firmly established that the potent adaptive immune responses initiated by pro-inflammatory $T$ cells activated via direct and indirect pathways in the host's secondary lymphoid organs are both necessary and sufficient to ensure acute rejection of most allografts (Benichou et al., 1992, 1999; Fangmann et al., 1993; Sayegh et al., 1994; Auchincloss and Sultan, 1996; Lee et al., 1997; Waaga et al., 1997). At the same time, it is now firmly established that the presence of alloreactive memory $\mathrm{T}$ cells or donor-specific antibodies in so-called sensitized recipients represents a formidable barrier to transplant tolerance induction (Adams et al., 2003a; Taylor et al., 2004; Valujskikh, 2006; Koyama et al., 2007; Weaver et al., 2009; Nadazdin et al., 2010, 2011; Yamada et al., 2011). Indeed, much effort is currently devoted to the elimination or inhibition of donor-specific memory T cells (TMEM) in primates, which, unlike laboratory mice, display high frequencies of alloreactive TMEM prior to transplantation (Nadazdin et al., 2010, 2011). Altogether, the majority of transplant immunologists have focused their efforts on the deletion and/or inactivation of alloreactive $\mathrm{T}$ and B cells, pre-transplantation. On the other hand, recent studies have proven beyond doubt that innate immunity is also an essential element of both acute and chronic rejection of allo- and xenografts (LaRosa et al., 2007; Alegre et al., 2008a,b; Alegre and Chong, 2009; Li, 2010; Goldstein, 2011; Murphy et al., 2011). Innate immune responses are initiated as a consequence of reperfusion injury, inflammation, tissue damage, and presumably microbial infections occurring at the time of transplantation (Figure 1). Different cells of the innate immune system can contribute to the rejection process both directly via secretion of soluble factors and destruction of donor grafted cells as well as indirectly by initiating or enhancing adaptive immune alloresponses while impairing the activation/expansion of protective regulatory $\mathrm{T}$ cells (Figure 1). At the same time, there is increasing evidence suggesting that different cells and molecules associated with innate immunity can hinder tolerance induction to allografts and xenografts (LaRosa et al., 2007; Alegre et al., 2008b; Wang et al., 2008; Murphy et al., 2011). 


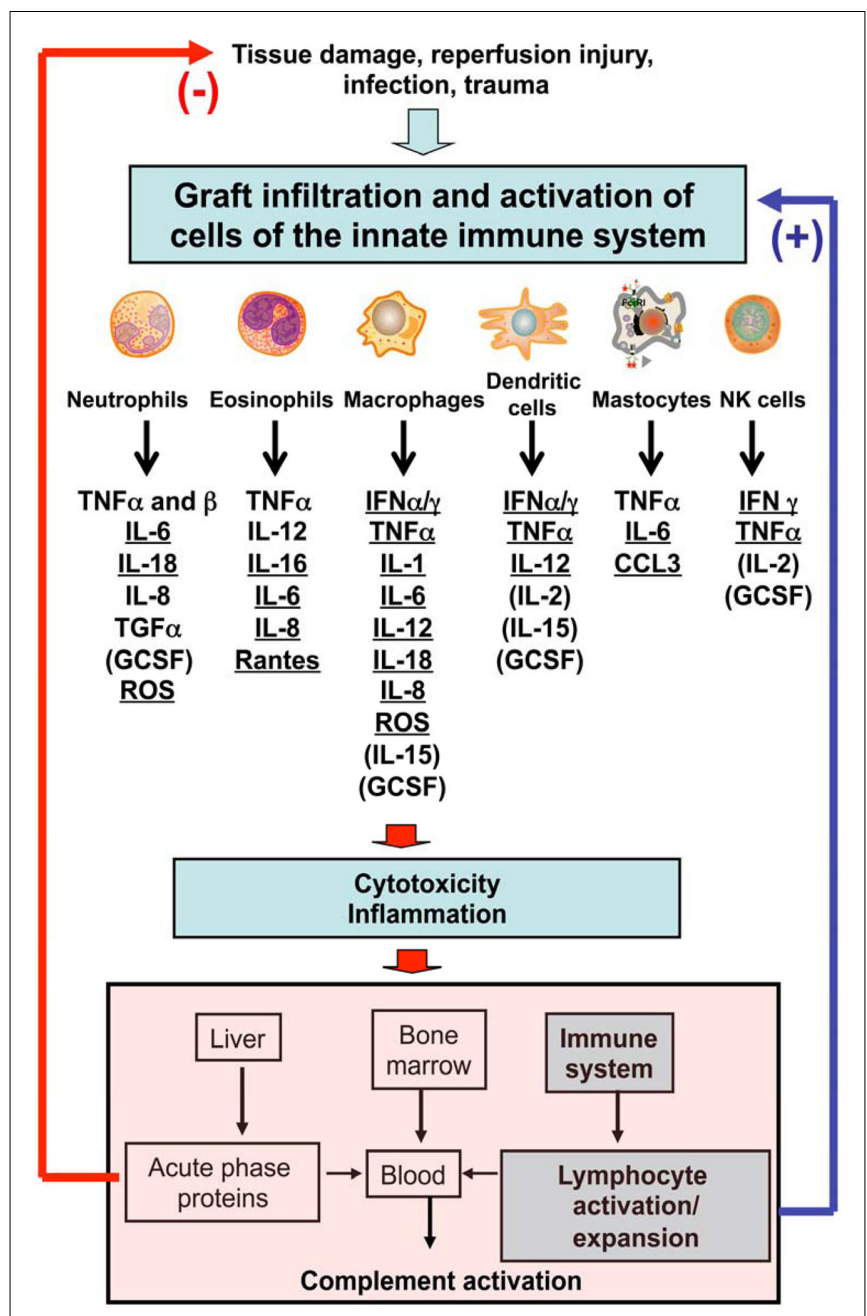

FIGURE 1 | Leukocytes and major cytokines involved in the innate immune response after allotransplantation.

At first glance, it can be speculated that all cells and molecules mediating graft rejection can potentially prevent tolerogenesis. However, immune rejection and tolerance resistance do not necessarily involve the same mechanisms and these two processes are likely to differ in nature and magnitude. This article reviews some of the mechanisms by which innate immunity can interfere with establishment or maintenance of tolerance to allogeneic transplants, an issue that is essential to the design of novel tolerance strategies in transplantation.

\section{RECEPTORS AND SOLUBLE MEDIATORS OF THE INNATE IMMUNE SYSTEM \\ TOLL-LIKE RECEPTORS}

Lymphocytes recognize exquisitely a vast array of molecular motifs via their antigen receptors generated through somatic recombination of gene segments during development. In contrast, cells of the innate immune system interact with a few conserved molecules expressed by microorganisms referred to as pathogenassociated molecular patterns (PAMPs; Medzhitov, 2001;
Medzhitov and Janeway, 2002). Among these pattern-recognition receptors (PRRs; Medzhitov, 2001; Elmaagacli et al., 2006; Uematsu and Akira, 2007), the Toll-like receptors (TLRs) have been extensively characterized and studied for their role in the initiation and amplification of innate immune responses (Iwasaki and Medzhitov, 2004; Pasare and Medzhitov, 2005). In addition, there is increasing evidence that tissue injury is associated with the delivery of signal delivered through TLRs by so-called damage-associated molecular patterns or DAMPs (Alegre et al., 2008a,b).

Until now, 10 different TLRs have been identified in humans (13 in mice), including TLRs 1, 2, 4, 5, and 6 expressed on the cell surface and TLRs 3, 7, 8, and 9 found in endosomal compartments (Rehli, 2002; Akira and Takeda, 2004; Akira et al., 2006). TLR1 is ubiquitously expressed while the other TLRs exhibit different expression patterns depending upon the type of leukocyte (Muzio et al., 2000; McCurdy et al., 2001; Hornung et al., 2002; Zarember and Godowski, 2002; Bourke et al., 2003; Caramalho et al., 2003; Hayashi et al., 2003; Nagase et al., 2003; Hart et al., 2005; Liu et al., 2006). On the other hand, all TLRs are expressed by epithelial cells while TLRs 5-10 are found in endothelial cells (Frantz et al., 1999) and other graft parenchymal cells depending upon the nature of the organ. All TLRs transduce their signal though the adapterprotein MyD88 (Barton and Medzhitov, 2003; Akira and Takeda, 2004) with the exception of TLR3 which uses the Toll-IL-1R (TIR) inducing IFN $\beta$ protein, TRIF (Frantz et al., 1999, 2001; Faure et al., 2000; Tsuboi et al., 2002; Harada et al., 2003; Mempel et al., 2003; Sukkar et al., 2006). TLR4 uses both MyD88 and TRIF during cell activation (Sakaguchi et al., 2003; Goriely et al., 2006; Molle et al., 2007). While the primary functions of TLRs is to ensure early detection of microbes and their products, these receptors have been shown to recognize autologous molecules expressed during the course of inflammatory processes such as nucleic acids released by necrotic cells, products of degraded extracellular matrices, heat shock proteins (HSP60 and HSP70 via TLR2 and TLR4; Asea, 2008), high mobility group box chromosomal protein 1 (TLRs 2, 4, and 9), and hyaluronan (TLR signaling via TIRAP; Mollen et al., 2006; Tesar et al., 2006; Ivanov et al., 2007; Kanzler et al., 2007; Tian et al., 2007). Transplant surgical procedures, which are associated with tissue damage and reperfusion injury trigger inflammatory reactions engaging the delivery of signals through TLRs and subsequent initiation of potent innate immune responses at the graft site. In addition, maturation and activation of donor and recipient dendritic cells (DCs) and other cells of the innate immune system via TLR ligation is essential to their ability to initiate and amplify adaptive immunity. This process involves the secretion of proinflammatory cytokines and chemokines (Shimamoto et al., 2006; Wu et al., 2007a) and subsequent activation of antigen processing pathways and the expression of costimulation and MHC molecules by APCs involved in antigen presentation to $\mathrm{T}$ and $\mathrm{B}$ lymphocytes (Bluestone, 1996). Therefore, TLRs are considered to be an essential link between innate and adaptive immunity. These observations suggest that TLRs play a key role in the initiation of innate immune responses and the recruitment and activation of alloreactive lymphocytes associated with allograft rejection. In support of this view, absence of MyD88 adaptor-protein in both donor and recipient mice has led to acceptance of minor antigen-mismatched 
skin allografts and prolonged survival of fully allogeneic heart and skin transplants (Goldstein et al., 2003; Tesar et al., 2004). Furthermore, combined deficiencies of MyD88 and TRIF and expressions in donors have been shown to significantly extend the survival of MHC-mismatched allografts. At the same time, there is accumulating evidence showing that TLR-mediated responses can hinder tolerance induction to allotransplants. First, it has been reported that long-term survival of skin allografts can be achieved in mice through costimulation blockade but only upon inhibition of TLR signaling in both donors and recipient mice (Chen et al., 2006; Walker et al., 2006). In another study, tolerance to cardiac allografts induced via donor-specific transfusion (DST) combined with antiCD40L mAb-mediated costimulation blockade was prevented by injection of the TLR9 agonist, CpG as well as the TLR2 ligand, Pam3CysK. In this study, tolerance resistance was attributed to increased $\gamma$ IFN production and inhibition of graft infiltration by regulatory $\mathrm{T}$ cells (Chen et al., 2006). Similarly, administration of CpG, LPS, or poly I:C which activate TLR 9, 4, and 3, respectively, prevented tolerance induction to skin allografts induced via DST + anti-CD40L mAbs. In this model, it was observed that TLR engagement prevented the deletion of some effector donor-specific $\mathrm{CD}^{+} \mathrm{T}$ cells (Thornley et al., 2006), a process relying on type I interferon production (Thornley et al., 2007). Finally, Turka's group recently reported that spontaneous tolerance to MHC class II-mismatched skin heart allografts as well as long-term acceptance of skin allografts mediated via anti-CD40L mAb and rapamycin cotreatment in the B6-bm12 mouse combination were both prevented by CpG administration (Porrett et al., 2008). In this study, prevention of tolerance was dependent on IL-12 production by APCs, which is critical to the differentiation of pro-inflammatory type 1 (Th1/CT1) immunity. Therefore, engagement of certain TLRs at the time of transplantation can hinder tolerance induction to allografts via concomitant enhancement of pro-inflammatory $\mathrm{T}$ cell responses and impairment of regulatory $\mathrm{T}$ cell functions.

\section{INFLAMMATORY CYTOKINES}

Certain pro-inflammatory cytokines produced by cells of the innate immune system can prevent tolerance induction to alloantigens or abrogate established tolerance of an allograft. For instance, IL-6 and TNF $\alpha$ deficiency has been shown to render mice susceptible to transplant tolerance induction via costimulation blockade (Walker et al., 2006; Shen and Goldstein, 2009). Apparently, IL6 and TNF $\alpha$ contributed to prevent tolerogenesis by enhancing pro-inflammatory immunity while rendering $\mathrm{T}$ cells resistant to suppression by Tregs (Walker et al., 2006; Shen and Goldstein, 2009). Likewise, type 1 interferons have been shown to confer tolerance resistance of skin allografts mediated via anti-CD154 mAb treatment in mouse models (Thornley et al., 2007). Tolerance resistance to vascularized allografts induced via costimulation blockade following Listeria monocytogenes infection has been shown to rely on IFN $\alpha$ and $\beta$ productions. In another study, evidence was provided that IL- 6 could prevent transplant tolerance to cardiac allografts induced through the disruption of CD40/CD40L interactions, by promoting the differentiation and activation of $\mathrm{CD}^{+}$ TH17 cells (Burrell et al., 2008).

IL- $1 \alpha$ is produced constitutively and at low levels by many epithelial cells but it is found in substantial amounts in the epidermis where its secretion by keratinocytes is thought to play a key role in the immune defense against microorganisms (Palmer et al., 2007; Arend et al., 2008; Dinarello, 2009; Gabay et al., 2010). In addition, during inflammation and sepsis, activated macrophages, and polymorphonuclear neutrophils (PMNs) produce large amounts of IL- $1 \alpha$ which is known to cause smooth muscle cell proliferation, secretion of $\mathrm{TNF} \alpha$ by endothelial cells, the synthesis of acute phase proteins, and amplify antigen-specific and alloreactive T and B cell responses (Rao et al., 2007, 2008; Rao and Pober, 2008; Dinarello, 2011a). IL-1 $\beta$, also called lymphocyte activating factor (LAF), is primarily released by activated macrophages during inflammation (Rao et al., 2007; Netea et al., 2010; Dinarello, 2011 b,c). It is involved in a variety of cellular activities, including cell proliferation, differentiation, and apoptosis. The induction of cyclooxygenase 2 (PTGS2/COX2) by this cytokine in various tissues including the central nervous system (CNS) is found to contribute to hypersensitivity reactions and pain. IL- $1 \alpha$ and $\beta$ play a role in mediating acute inflammation during ischemiareperfusion (I/R) injury after transplantation (Suzuki et al., 2001). Ischemia and hyperoxia/anoxia both contributes to the release of IL-1 by macrophages (from the NALP-3 inflammasome), a process leading to both necrosis and apoptosis of transplanted cells, neutrophilic inflammation and initiation, and amplification of adaptive immune responses (Wanderer, 2010). Indeed, it has been shown that overexpression of IL-1R antagonist (IL$1 \mathrm{Ra}$ ) can confer cardioprotection against $\mathrm{I} / \mathrm{R}$ injury associated with reduction in cardiomyocyte apoptosis and decrease of neutrophil infiltration and myocardial myeloperoxidase activity in heart-transplanted rats (Suzuki et al., 2001).

There are a few reports showing that IL-1 can prevent tolerance induction to allografts. IL- $1 \beta$ is known to contribute to the breakdown of self-tolerance to pancreatic autoantigens resulting in type 1 diabetes in NOD mice (Bertin-Maghit et al., 2011). This effect is mediated via both induction of TH17 autoimmunity and concomitant impairment of Treg differentiation and functions. Likewise, it has been shown that IL-1 can prevent the induction of tolerance to islet allografts (Sandberg et al., 1993). This is supported by studies showing that continuous infusion of diabetic mice with an IL-1 receptor antagonist (IL-1Ra) can restore normoglycemia and facilitate tolerance to islet allografts (Sandberg et al., 1993). Similarly, alpha-1 anti-trypsin therapy (AAT) has been shown to promote donor-specific tolerance to islet allografts in mice via a process relying on the presence of immature DCs (iDCs) and Tregs in the graft associated with the presence of IL-1Ra (Lewis et al., 2008; Shahaf et al., 2011). In another set of studies by Holan (1988), it was observed that transplantation tolerance induced via inoculation of newborn mice with semi-allogeneic hematopoietic cells was abolished via administration of IL-1 given at the time of placement of skin allografts (Holan, 1988). Finally, a series of studies from Dana and Streilein's groups have shown that IL-1Rabased therapy can restore anterior chamber-associated immune deviation (ACAID) type tolerance associated with immune privilege in the eye and acceptance of allogeneic corneal transplants (Dana et al., 1997, 1998; Yamada et al., 1998, 2000; Dekaris et al., 1999). Interestingly, IL-1Ra treatment in this model was shown to abolish donor-specific DTH, reduce corneal graft infiltration by recipient Langerhans cells and abrogate second set rejection of 
skin allografts suggesting an impaired antigen presentation and a lack of systemic priming of alloreactive $\mathrm{T}$ cells through the indirect allorecognition pathway in draining lymph nodes (Dana et al., 1997, 1998; Yamada et al., 1998, 2000; Dekaris et al., 1999).

\section{CHEMOKINES}

Chemokines represent an extensive family of proteins whose function was initially associated with leukocyte chemotaxis. It is now clear that these molecules are also involved in a variety of biological processes including angiogenesis and hematopoiesis (Sallusto et al., 2000). There is ample evidence showing that chemokines play a key role in the initiation of alloantigendependent and alloantigen-independent reactions associated with transplant injury as well as acute and chronic rejection of allografts (DeVries et al., 2003). Likewise, many studies have shown that absence (KO mouse models) or in vivo neutralization of various chemokines or chemokine receptors, usually combined with short-term or suboptimal calcineurin inhibitory treatment, results in prolonged and sometimes indefinite survival of allografts in animal models (Gao et al., 2000, 2001; Hancock et al., 2000a,b; Fischereder et al., 2001; Abdi et al., 2002). These observations suggest that chemokine release as well as leukocyte activation and migration following chemokine receptor signaling should represent a barrier to transplant tolerance induction and/or maintenance. On the other hand, a number of chemokines have been associated with Treg activation and graft infiltration and are clearly necessary for tolerance induction in transplantation (DeVries et al., 2003).

\section{THE COMPLEMENT SYSTEM}

The complement system is comprised of a variety of small proteins including serum proteins, serosal proteins, and cell surface receptors (over 25 proteins and protein fragments, $5 \%$ of serum globulin fraction) present in the blood, generally synthesized by the liver, and normally circulating as inactive precursors (pro-proteins; Carroll, 1998; Kang et al., 2009).

When stimulated, the proteases in the system cleave specific proteins and subsequent cytokine release thus initiating an amplifying cascade of further cleavages. The end-result of this activation cascade is a massive amplification of the response and activation of the cell-killing membrane attack complex or MAC (Peitsch and Tschopp, 1991). Three distinct pathways are involved in complement activation: the classical pathway, the alternative pathway, and the mannose-binding lectin pathway (Sacks et al., 2009). All of these pathways converge on $\mathrm{C} 3$ whose cleavage leads to the release of soluble C3a and C5a. It is noteworthy that while $80 \%$ of C3 is synthesized in the liver, $20 \%$ of C3 is of extra hepatic origin and produced by resident parenchymal cells and infiltrating leukocytes (Naughton et al., 1996; Tang et al., 1999; Li et al., 2007). $\mathrm{C} 3 \mathrm{a}$ and $\mathrm{C} 5 \mathrm{a}$ have anaphylatoxin properties and trigger directly mast cell degranulation and increase vascular permeability and smooth muscle contraction. Most importantly, the complement has opsonizing and chemotactic functions in that it enhances antigen phagocytosis and attracts macrophages and PMNs at the site of inflammation. The complement system represents an essential component of the inflammatory cascade and a major link between innate and adaptive immunity. Likewise, there is now a body of evidence showing that the complement is an essential element of the inflammatory process as well as the immune response associated with the rejection of allogeneic transplants (Zhou et al., 2007; Raedler et al., 2009; Raedler and Heeger, 2010; Vieyra and Heeger, 2010). First, many studies have demonstrated the contribution of the complement to I/R injury following transplantation of a variety of organs including liver, kidney, and lungs (Weisman et al., 1990; Ikai et al., 1996; Eppinger et al., 1997; Huang et al., 1999; Zhou et al., 2000; Chan et al., 2006; Farrar et al., 2006; Patel et al., 2006). Remarkably, mice lacking complement have been shown to be unable to make high affinity anti-MHC antibodies after skin transplantation. This was due to the lack of CR2 expression, a coreceptor that is required for antigen retention by follicular DCs (Fearon and Carroll, 2000; Marsh et al., 2001; Pratt et al., 2002). On the other hand, the complement plays an important role in the antigen processing presentation by DCs and controls their ability to activate T cells in antigen-specific fashion. Finally, elegant studies from the Heeger's group and others have demonstrated the role of $\mathrm{C} 3$ in the activation and expansion of both $\mathrm{CD} 4^{+}$and $\mathrm{CD} 8^{+}$ T cells presumably by limiting antigen-induced apoptosis (Fearon and Carroll, 2000; Marsh et al., 2001; Pratt et al., 2002; Peng et al., 2006, 2008; Zhou et al., 2006; Lalli et al., 2008; Strainic et al., 2008). Altogether, these studies suggest that activation of the complement cascade following transplantation should render tolerance difficult to induce. In support of this view, it has been shown that blockade of complement activation on DCs results in an increase of Treg expansion and favors tolerance induction (Sacks et al., 2009).

\section{CELLS OF THE INNATE IMMUNE SYSTEM NK CELLS}

Natural killer (NK) cells contribute to the innate immune response through their ability to recognize and destroy foreign cells in the absence of antigen-specific recognition (Hamerman et al., 2005). However, although NK cells lack expression of germline-encoded antigen receptors, they can discriminate between self- and foreign cells via clonotypic receptors recognizing self-MHC class I molecules. NK cell interacting with self-MHC class I expressed on autologous cells become inactivated while lack or suboptimal recognition of self-MHC class I molecules (missing self phenomenon) on allogeneic cells results in NK cell stimulation associated with release of pro-inflammatory cytokines and cytotoxicity (Karre et al., 1986; Ljunggren and Karre, 1990; Ljunggren et al., 1990). This type of allorecognition has been shown to ensure the destruction of skin grafts from donors lacking self-MHC class I expression (b2m KO) as well as bone marrow transplants from semi-allogeneic donors and parental donors to F1 recipients (hybrid resistance; Karlhofer et al., 1992, 2006). In addition, recent evidence has been provided showing that NK cells also contribute to the rejection of solid organs transplants (Oertel et al., 2000, 2001; Kitchens et al., 2006; McNerney et al., 2006; van der Touw and Bromberg, 2010). NK cells participate in acute allograft rejection either directly by killing donor cells through perforin, granzymes, FasL, and TRAIL pathways (Biron et al., 1999; Smyth et al., 2001; Takeda et al., 2001; Trapani and Smyth, 2002) or indirectly by promoting alloantigen processing and presentation by DCs and B cells (Boehm et al., 1997) and by enhancing Type $1 \mathrm{~T}$ cell adaptive alloimmunity primarily though their secretion of $\gamma$ IFN and TNF $\alpha$ (Martin-Fontecha et al., 2004; Yoshida et al., 
2008). Furthermore, NK cells have been shown to contribute to the rejection process by killing regulatory T cells (Roy et al., 2008). Finally, some recent studies have demonstrated the pivotal role of NK cells in chronic rejection of cardiac allografts through a process involving CD4 ${ }^{+} \mathrm{T}$ cell activation (Uehara et al., 2005a,b). Altogether, these studies support the view that NK cells represent an essential link between innate and adaptive immune responses leading to acute and chronic rejection of allogeneic transplants. On the other hand, a study from Szot et al. (2001) has demonstrated that NK cells can also impair tolerance induction to a solid organ transplant. In this model, injection of recipient CD28-deficient mice with anti-CD154 antibodies failed to accomplish indefinite survival of cardiac allografts. However, tolerance to heart allografts was restored upon in vivo depletion of NK cells or inhibition of the NK activating receptor, NKGD. Apparently, NK cells activated consequently to the absence of self-MHC class I molecules on transplanted cells could provide help (otherwise missing in $\mathrm{CD} 28 \mathrm{KO}$ mice) to $\mathrm{CD}^{+} \mathrm{T}$ cells and thereby prevented tolerance induction (Maier et al., 2001; Kim et al., 2007).

\section{DENDRITIC CELLS}

Dendritic cells are considered as the primary link between innate and adaptive immunity based on their ability to prime naïve $\mathrm{T}$ cells owing to: (1) efficient processing and presentation of antigen peptides in association with self-MHC molecules and, (2) the delivery of key costimulation signals (Steinman and Cohn, 1973; Austyn et al., 1983, 1988; Banchereau and Steinman, 1998; Lanzavecchia and Sallusto, 2000, 2001; Steinman et al., 2000). Actually, the $\mathrm{T}$ cell alloresponse is primarily initiated through the recognition of intact donor-MHC molecules on donor DCs infiltrating the recipient's secondary lymphoid organs (direct allorecognition; Steinman and Witmer, 1978; Lechler and Batchelor, 1982; Larsen et al., 1990a,b,c,d; Lechler et al., 1990; Larsen and Austyn, 1991). The direct alloresponse is believed to represent the driving force behind acute allograft rejection. Alternatively, some alloreactive T cells become activated after recognition of donor peptides (MHC and minor antigens) presented by self-MHC molecules on recipient DCs (indirect allorecognition; Benichou et al., 1992, 1999; Dalchau et al., 1992; Fangmann et al., 1992; Liu et al., 1996; Sayegh and Carpenter, 1996). The mechanisms by which recipient DCs acquire donor alloantigens are still unknown. The direct alloresponse is believed to be short-lived due to the rapid elimination of donor DCs, while the indirect alloresponse may be perpetuated by continuous presentation of donor peptides by recipient APCs. While it is clear that indirect alloreactivity is sufficient to trigger vigorous rejection of skin allografts, whether this response plays a significant role in acute rejection of vascularized solid organ transplants is still open to question (Auchincloss et al., 1993; Lee et al., 1994, 1997; Illigens et al., 2002). On the other hand, maintenance of indirect alloresponses via continuous presentation of allopeptides by recipient DCs and endothelial cells is clearly associated with alloantibody production, chronic inflammation, and allograft vasculopathy (Suciu-Foca et al., 1996, 1998; Shirwan, 1999; Baker et al., 2001; Lee et al., 2001; Najafian et al., 2002; Shirwan et al., 2003; Yamada et al., 2003; Illigens et al., 2009). Finally, some recent studies show that recipient DCs can capture donor-MHC molecules and presumably other donor proteins from donor DCs and endothelial through a process called trogocytosis (Joly and Hudrisier, 2003; Aucher et al., 2008). Theoretically, presentation of intact allo-MHC molecules by host professional APCs could activate some alloreactive T cells, a mechanism referred to as semidirect allorecognition. While, it has been shown that DCs having acquired donor-MHC molecules can activate $\mathrm{T}$ cells in vitro and in vivo, the actual contribution of semi-direct alloreactivity to the alloresponse and allograft rejection is still unknown (Herrera et al., 2004; Smyth et al., 2006, 2007).

Dendritic cells consist of a diverse population of cells characterized by a few common surface markers and some functional characteristics (Banchereau and Steinman, 1998; Liu et al., 2009). In addition, DC functions can differ dramatically depending upon their degree of maturation (Steinman et al., 2003; Wilson and Villadangos, 2004). Myeloid iDCs, which have not yet encountered antigens or become activated via PAMPs or cytokine exposure, express low levels of MHC class II and costimulatory receptors and are poor APCs. Presentation of alloantigens by these iDCs has been associated with peripheral tolerance induction (Fu et al., 1996; Dhodapkar et al., 2001; Roncarolo et al., 2001) and immune privilege (Stein-Streilein and Streilein, 2002; Streilein et al., 2002; Masli et al., 2006) presumably via T cell anergy (Fu et al., 1996; Dhodapkar et al., 2001; Roncarolo et al., 2001). In contrast, DCs (mDCS) which underwent maturation following antigen uptake and processing in an inflammatory cytokine environment or exposure to PAMPs and presumably DAMPs express high levels of MHC class II and costimulation receptors are potent inducers of type 1 alloimmunity after transplantation (Rogers and Lechler, 2001). Alternatively, plasmocytoid DCs (pDCs), which represent a small population of DCs mostly located in the peripheral blood, are thought to contribute to tolerance induction via IL-10 secretion following ICOS costimulation and presumably induction of regulatory T cell responses (Abe et al., 2005; Liu, 2005; Ochando et al., 2006; Ito et al., 2007; Tokita et al., 2008; Matta et al., 2010). Finally, seminal studies by Thomson and others have shown that physical or chemical modifications of DCs can render them tolerogenic (Bacci et al., 1996; Kurimoto et al., 2000; Lu and Thomson, 2002; Thomson, 2002; Morelli and Thomson, 2003; Turnquist et al., 2007) and ensure long-term survival to allografts upon their in vivo transfer to recipients ( $\mathrm{Lu}$ and Thomson, 2002; Thomson, 2002; Morelli and Thomson, 2003; Turnquist et al., 2007).

Altogether, these studies emphasize that DCs represent an essential link between innate and adaptive alloimmunity by serving as APCs for alloantigen presentation to $\mathrm{T}$ cells, by providing critical costimulation signals, and by secreting cytokines both at the site of grafting and in the host's lymphoid tissues and organs. At the same time, it has become evident that the role of DCs in the alloimmune response and rejection process is extremely complex and depends on many factors including the origin (recipient or donor) of the DCs, the nature of the DCs, their level of maturation, and the environment in which they become activated. It was initially assumed that donor or recipient DCs might hinder tolerance induction to allografts owing to their contribution to the priming of alloreactive $\mathrm{T}$ cells and the secretion of proinflammatory cytokines. Based upon this principle, many attempts have been made to deplete DCs from transplanted tissues or from the host prior to tolerance induction. Actually, DC depletion has 
led to various and sometimes opposite outcomes depending upon the nature of the tissue transplanted, the site of graft placement, the method utilized to induce tolerance. For instance, depletion of different DCs from skin transplants such as Langerhans cells or dermal DCs can lead to opposite effects on allograft rejection (Bobr et al., 2010; Igyarto and Kaplan, 2010; Igyarto et al., 2011).

On the overall, most studies showed that absence of DCs, either from recipients or donors in studies using CD11C KO mice, graft parking protocols, or antibody-mediated cell depletion, not only regularly failed to significantly prolong graft survival but it often prevented tolerance induction. This further supports the view that DCs are necessary for antigen presentation during tolerogenesis via their ability to trigger some regulatory mechanisms resulting in graft protection. Further studies will be needed to discriminate between the DCs, which promote or hinder tolerance to allografts and the mechanisms by which they determine the fate of regulatory $\mathrm{T}$ cell responses. Gaining insights into these questions will be necessary to delete or inactivate selectively the DCs associated with tolerance resistance in transplantation.

\section{GRANULOCYTES, MASTOCYTES, AND MONOCYTES/MACROPHAGES}

Granulocytes, mastocytes, and monocytes/macrophages are traditionally considered as key players in both early innate alloimmune response and in the actual destruction of donor cells after transplantation. However, the mechanisms by which they contribute to alloimmunity and the actual nature of their contribution to allograft rejection have not been thoroughly investigated. Likewise, little is known regarding the impact of these cells in transplantation tolerance. This section reviews some of the few studies that have tackled these questions.

Granulocytes are the most abundant leukocytes in the blood of mammals and an essential part of the innate immune system. Among them, PMNs migrate within hours to the site of acute inflammation after transplantation following chemical signals such as IL-8, C5a, and Leukotriene B4 in a process called chemotaxis. However, they survive only 1-3 days at the graft site where they undergo degranulation and release reactive oxygen species (ROS), a process involving the activation of NADPH oxidase and the production of superoxide anions and other highly reactive oxygen metabolites which cause tissue damage (Jaeschke et al., 1990). There is ample evidence showing that PMNs contribute to donor tissue destruction and graft rejection in skin transplantation, solid organ transplantation, and bone marrow transplantation (Buonocore et al., 2004; Surquin et al., 2005). Studies from the Fairchild's group have demonstrated that Abs directed to KC/CXCL1 can prolong cardiac allograft survival by preventing PMNs from graft infiltrating the graft (Morita et al., 2001; LaRosa et al., 2007). Additionally, the potential role of PMNs in the prevention of tolerance induction has been examined in two recent studies, only. First, it has been reported that peritransplant elimination of PMNs facilitated tolerance to fully mismatched cardiac allografts induced via costimulation blockade (El-Sawy et al., 2005; Mollen et al., 2006; LaRosa et al., 2007). Most interestingly, another study from Wood's group shows that prevention of accelerated rejection of skin allografts by $\mathrm{CD} 8^{+}$effector memory T cells could be achieved by Tregs but only following depletion of PMNs (Jones et al., 2010). It is likely that elimination of PMNs created a window of opportunity that permitted Treg-mediated suppression of graft rejection. Indeed, it well established that early activation of pre-existing alloreactive memory $\mathrm{T}$ cells represents a formidable barrier to tolerance induction in transplantation (Valujskikh et al., 2002; Adams et al., 2003b; Valujskikh and Heeger, 2003; Weaver et al., 2009; Nadazdin et al., 2011). In the model described above, PMNs did not prevent tolerance induction directly but indirectly by hindering the suppression of memory $\mathrm{T}$ cells by Tregs. It is possible that this phenomenon represents a general mechanism by which innate immunity prevent transplant tolerance induction through the potentiation of alloreactive memory $\mathrm{T}$ cells. This implies that blocking innate immune responses at the time of graft placement may impair the development of anamnestic alloresponses by $\mathrm{T}$ cells and render allograft susceptible to tolerogenesis by regulatory responses induced after costimulation blockade or mixed hematopoietic chimerism induction, a hypothesis that requires further investigation.

Eosinophils play a key role in the pathogenesis associated with allergic reactions through their production of inflammatory cytokines and cationic proteins (Capron and Goldman, 2001). These cells can drive the differentiation of T cells to TH2 immunity essentially via IL-4 and IL-5 cytokine release (Sanderson, 1992; Kay et al., 1997). TH2 cells that exert antagonist properties toward their pro-inflammatory $\mathrm{TH} 1$ counterparts were initially thought to be potential contributors to tolerogenesis in autoimmune diseases and transplantation (Charlton and Lafferty, 1995; Goldman et al., 2001). Indeed, TH2 polarization has been demonstrated to be essential in neonatal tolerance induction and in some allotransplant models (Hancock et al., 1993; Forsthuber et al., 1996; Onodera et al., 1997; Yamada et al., 1999; Kishimoto et al., 2000; Waaga et al., 2001; Fedoseyeva et al., 2002). However, it became rapidly evident that this concept is over simplistic and that eosinophils either directly or via the activation of TH2 cells can trigger the rejection of allografts in various models (Illigens et al., 2009). First, there is ample evidence showing that adoptively transferred allospecific TH2 cells can ensure on their own the rejection of skin and cardiac allogeneic transplants (Piccotti et al., 1996, 1997; VanBuskirk et al., 1996; Shirwan, 1999). Second, IL-4 and IL-5 neutralization has been shown to delay the rejection of allografts in several models (Chan et al., 1995; Simeonovic et al., 1997; Matesic et al., 1998; Le Moine et al., 1999; Braun et al., 2000; Honjo et al., 2000; Goldman et al., 2001; Surquin et al., 2005). In the B6-bm12 MHC class II classical skin graft model, rejection has been associated with a massive infiltration by eosinophils (Le Moine et al., 1999; Goldman et al., 2001). IL-5 blockade delayed the rejection process by preventing eosinophilic infiltration, but these allografts were ultimately rejected via a mechanism involving PMNs (Le Moine et al., 1999; Goldman et al., 2001). In another study from the Martinez's group, the existence of a non-classical pathway of liver allograft rejection was shown to involve IL-5 and graft infiltrating eosinophils secreting a series of cytotoxic mediators including eosinophil peroxidase, eosinophilderived neurotoxin, eosinophil cationic protein, and major basic protein (MB; Martinez et al., 1993). In addition, a number of studies from us and others have provided direct evidence demonstrating that alloreactive $\mathrm{TH} 2$ cells activated through the indirect allorecognition pathway can trigger chronic allograft vasculopathy 
and tissue fibrosis in MHC class I-mismatched transplanted hearts (Shirwan, 1999; Mhoyan et al., 2003; Koksoy et al., 2004; Illigens et al., 2009). At the same time, it has been reported that, in models in which acute rejection had been suppressed, eosinophilic graft infiltration could induce fibrosis through their production of TGF$\beta$, a key mediator of extracellular matrix remodeling (Goldman et al., 2001). It is noteworthy that eosinophils are likely to play a prominent role in heart and lung transplantation through their cooperation with activated mast cells associated with IL-9 release (Dong et al., 1999; Marone et al., 2000; Suzuki et al., 2000; Cohn et al., 2002; Poulin et al., 2003; Steenwinckel et al., 2007). Interestingly, it has been observed that depletion of $\mathrm{CD} 8^{+} \mathrm{CT} 1$ cells and subsequent deprivation of $\gamma$ IFN production or IL-12 antagonism can result in a polarization of the $\mathrm{T}$ cell response toward $\mathrm{TH} 2$ alloimmunity and cause eosinophilic rejection of cardiac allografts primarily driven by IL-4 and IL-5 cytokines (Noble et al., 1998; Foucras et al., 2000; Goldman et al., 2001). This further illustrates the complexity of the alloimmune response and the multiplicity of the mechanisms potentially involved in the rejection process. Indeed, as often observed in autoimmune disease models, blocking a known deleterious type of alloimmunity can often uncover a different type of response also leading to allograft rejection.

Mastocytes were originally described by Paul Ehrlich in his 1878 doctoral thesis on the basis of their unique staining characteristics and large granules (Alvarez-Errico et al., 2009; Barnes, 2011). These cells typically found in mucosal and connective tissues (skin, lungs, and intestines) are characterized by their high expression of IgE high affinity $\mathrm{Fc}$ receptor $(\mathrm{FcR})$ and $\mathrm{IgG} 1$ (in mice) FcR. Mast cells are known for their pivotal role in immunity against parasitic worms and their contribution to allergic reactions (asthma, eczema, allergic rhinitis, and conjunctivitis). This phenomenon is mediated mainly through degranulation of serine proteases, histamine, and serotonin and through recruitment of eosinophils at the site of inflammation via the secretion of eosinophil chemotactic factors (Alvarez-Errico et al., 2009; Barnes, 2011). Mast cells are also essential to the recruitment of $\mathrm{T}$ cells to the skin and joints in autoimmune disorders including rheumatoid arthritis, bullous pemphigoid, and multiple sclerosis (Sayed and Brown, 2007; Sayed et al., 2008; Schneider et al., 2010). The role of mastocytes in allotransplantation was actually described in seminal studies for the Voisin's laboratory more than 40 years ago. It was observed that non-complement fixing anaphylactic IgG1 and IgE antibodies directed to donor-MHC molecules can cause rejection of skin allografts through a process called alloantibodyinduced anaphylactic degranulation (DAAD; Daeron et al., 1972, 1975, 1980; Le Bouteiller et al., 1976; Daeron and Voisin, 1978, 1979; Benichou and Voisin, 1987). Hyperacute rejection of skin allografts was induced through bipolar bridging of mastocytes (through their FcR) and donor-MHC molecules on grafted cells, a process leading to a massive anaphylactic reaction leading to allograft rejection (Daeron et al., 1972, 1975, 1980; Le Bouteiller et al., 1976; Daeron and Voisin, 1978, 1979). This type of "allergic transplant rejection" discovered during the 1960s has been largely forgotten through the years and would deserve to be revisited using newly developed immunological models. More recently, it has been shown that degranulating mastocytes can contribute to allograft rejection by causing the loss of Tregs and thereby prevent tolerance induction in a skin allograft model (de Vries et al., 2009a; Murphy et al., 2011). While Tregs can induce the maturation and growth of mastocytes through IL-9 production, this process seems rather to contribute to tolerance induction (Lu et al., 2006; Murphy et al., 2011). In addition, sequestration of pro-inflammatory IL-6 cytokines by mastocytes through MCP6 receptors has also been shown to promote establishment of tolerance to lung and cardiac allografts via costimulation blockade (de Vries et al., 2009a,b, 2010; de Vries and Noelle, 2010; Murphy et al., 2011). Therefore, the role of mastocytes in alloimmunity is more complex than initially anticipated and further studies will be required to determine how these cells can prevent or promote tolerance induction in skin and presumably lung transplantation.

Different macrophages derived from monocyte differentiation are present in various tissues and organs including Kupffer cells in the liver, microglial cells in the CNS, alveolar macrophages in the lungs, and intraglomerular mesangial cells in the kidney (Lu and Unanue, 1982; Unanue, 1984; Yan and Hansson, 2007; Varol et al., 2009; Geissmann et al., 2010; Yona and Jung, 2010). These cells are characterized by the surface expression of CD14, CD11b, F4/80 (mice)/EMR1 (humans) as well as MAC1/3 and CD68. Macrophages and monocytes rapidly infiltrate inflammation sites and are typically found in large numbers within allografts (Geissmann et al., 2010). Upon activation, they release large amounts of pro-inflammatory cytokines such as TNF $\alpha$, IL-12 IL-1, and IL6 , which promote both innate and adaptive immune responses (Geissmann et al., 2010). Macrophages play a key role in the induction of antibody dependent cellular cytotoxic (ADCC) reactions leading to the phagocytosis of opsonized allogeneic target cells (Unanue and Allen, 1986; Rocha et al., 2003; Li, 2010). During acute inflammation, while PMNs are typically the first phagocytes infiltrating allografts, macrophages are usually involved in secondary stages of inflammation during which they remove aged PMNs via a mechanism involving PECAM-1 (CD31) as well as necrotic cells and cellular debris (Davies et al., 1993; Wu et al., 2007b; Roh et al., 2010; Wu and Madri, 2010). Macrophages have also been shown to be essential to the maintenance of chronic inflammatory processes (Yan and Hansson, 2007; Geissmann et al., 2010). Likewise, some evidence has been provided suggesting that macrophages contribute to transplant vasculopathy and fibrosis (Davies et al., 1993; Kitchens et al., 2007; Yan and Hansson, 2007; Bani-Hani et al., 2009; Dinarello, 2011b; Kamari et al., 2011). In addition to their role in innate immunity, macrophages process, and present alloantigens to $\mathrm{CD} 4^{+} \mathrm{T}$ cells in a MHC class II context thus initiating $\mathrm{T}$ cell-mediated responses and rejection (Beller and Unanue, 1980; Lu et al., 1981; Unanue and Allen, 1986; Unanue, 2002; Calderon et al., 2006). Some observations indicate that, in stable transplants, macrophages can convert otherwise harmless lymphocytes into aggressive ones and cause rejection, thereby controlling the cytopathic features of cellular infiltrates in solid organ transplants (Li, 2010). Likewise, some studies have shown the beneficial effects of blockage of the macrophage-migration inhibitory factor (MIF) on the pathogenesis of allografts including the reduction of obstructive bronchiolitis after lung transplantation (Fukuyama et al., 2005; Javeed and Zhao, 2008). A study from Heeger's group has shown that in vivo blockade of MIF could prevent the rejection of MHC class II KO skin allografts in mice 
mediated through the indirect allorecognition pathway (Hou et al., 2001; Demir et al., 2003). In this model, neutralization of MIF resulted in reduced DTH response while it did not affect $\gamma$ IFN production by activated T cells (Hou et al., 2001; Demir et al., 2003). It is, however, noteworthy that different types of macrophages can be found in kidney allografts, some of which being involved in attenuation of inflammation, activation of Tregs, and tolerance induction (Lu et al., 2006; Brem-Exner et al., 2008; Hutchinson et al., 2011). Recently, macrophages have been shown to be involved in self-nonself discrimination, i.e., self-awareness via interaction between the innate inhibitory receptor SIRP $\alpha$ expressed on their surface and CD47. This type of recognition, which is reminiscent of the missing self-model described with NK cells, has been shown to play a role in xenograft rejection by macrophages (Ide et al., 2007; Wang et al., 2007; van den Berg and van der Schoot, 2008). However, it is still unclear whether some degree of CD47 polymorphism within a given species exists and whether it could be involved in allorecognition.

\section{CONCLUDING REMARISS}

It is now firmly established that innate immune responses triggered after transplantation as a consequence of tissue damage, infections, and reperfusion injury are an essential element of the inflammatory process leading to early rejection of allografts. In addition, there is accumulating evidence showing the contribution of innate immunity to chronic rejection of allogeneic transplants. On the other hand, this review supports the view that activation of virtually any of the cells of the innate immune system can prevent transplant tolerance induction. This process is essentially mediated via signaling of various receptors including TLRs (via DAMPS and PAMPS) and the secretion of several key pro-inflammatory cytokines (primarily IL- 1, IL- $6, \mathrm{TNF} \alpha$, and type I interferons) and chemokines. Activated cells of the innate immune system can prevent tolerogenesis directly via cytokine secretion, activation of the complement cascade, and killing of donor cells or indirectly by promoting and amplifying deleterious inflammatory adaptive immune responses while preventing the activation of protective

\section{REFERENCES}

Abdi, R., Tran, T. B., Sahagun-Ruiz, A., Murphy, P. M., Brenner, B. M., Milford, E. L., and McDermott, D. H. (2002). Chemokine receptor polymorphism and risk of acute rejection in human renal transplantation. $J$. Am. Soc. Nephrol. 13, 754-758.

Abe, M., Wang, Z., de Creus, A., and Thomson, A. W. (2005). Plasmacytoid dendritic cell precursors induce allogeneic T-cell hyporesponsiveness and prolong heart graft survival. Am. J. Transplant. 5, 1808-1819.

Adams, A. B., Pearson, T. C., and Larsen, C. P. (2003a). Heterologous immunity: an overlooked barrier to tolerance. Immunol. Rev. 196, 147-160.

Adams, A. B., Williams, M. A., Jones, T. R., Shirasugi, N., Durham, M. M., Kaech, S. M., Wherry, E. J., Onami,
T., Lanier, J. G., Kokko, K. E., Pearson, T. C., Ahmed, R., and Larsen, C. P. (2003b). Heterologous immunity provides a potent barrier to transplantation tolerance. J. Clin. Invest. 111, 1887-1895.

Ahmed, E. B., Wang, T., Daniels, M., Alegre, M. L., and Chong, A. S. (2011a). IL-6 induced by Staphylococcus aureus infection prevents the induction of skin allograft acceptance in mice. Am. J. Transplant. 11, 936-946.

Ahmed, E. B., Daniels, M., Alegre, M. L., and Chong, A. S. (2011b). Bacterial infections, alloimmunity, and transplantation tolerance. Transplant. Rev. (Orlando) 25, 27-35.

Akira, S., and Takeda, K. (2004). Tolllike receptor signalling. Nat. Rev. Immunol. 4, 499-511.

regulatory mechanisms. In addition, innate immune responses can alter the immune privileged nature of the tissue transplanted or the site of graft placement as evidenced by studies in corneal transplantation. While, it is clear that innate immunity represents a major barrier to tolerogenesis in allotransplantation, this phenomenon is presumably even more relevant to xenotransplantation due to the involvement of natural antibodies, CD47/SIRP $\alpha$-mediated interactions, and presumably many other still unknown factors. In addition, it is likely that activation of innate type of immunity can abrogate formerly established tolerance to an allograft as suggested by some studies involving microbial infections (Miller et al., 2008; Ahmed et al., 2011a,b). Taken together, these studies imply that the design of future successful tolerance protocols in transplantation will require the administration of agents capable of suppressing innate immunity. However, a number of cells of the innate immune system such as NK cells and DCs have been shown to be required for transplant tolerance induction. This apparent contradiction may be explained by the fact that different cell subsets and mediators of the innate immune system are involved in tolerance vs. rejection. Alternatively certain cells or mediators may play opposite roles depending upon the context in which they are activated. For instance, $\gamma$ IFN and IL-2 have been shown to be essential cytokines in both rejection and tolerance of allografts. It is likely that their dual role depends upon their concentration at a given time point and the cells they are activating in a particular physiological context. These observations illustrate the complexity of the cellular and molecular mechanisms by which innate immunity can influence alloimmunity toward rejection or tolerance. Further dissection of the innate immune response will be required to grasp some of this complexity, at least enough to be able to manipulate this type of immune response to our advantage.

\section{ACKNOWLEDGMENTS}

This work was supported by grants from the MGH ECOR and NIAID AI066705 grants to Gilles Benichou and NIH U191066705, PO1HL18646, and ROTRF 313867044 to Joren C. Madsen.

Akira, S., Uematsu, S., and Takeuchi, O. (2006). Pathogen recognition and innate immunity. Cell 124, 783-801.

Alegre, M. L., and Chong, A. (2009). Toll-like receptors (TLRs) in transplantation. Front. Biosci. (Elite Ed) 1, 36-43.

Alegre, M. L., Goldstein, D. R., and Chong, A. S. (2008a). Toll-like receptor signaling in transplantation. Curr. Opin. Organ Transplant. 13, 358-365.

Alegre, M. L., Leemans, J., Le Moine, A., Florquin, S., De Wilde, V., Chong, A., and Goldman, M. (2008b). The multiple facets of toll-like receptors in transplantation biology. Transplantation 86, 1-9.

Alvarez-Errico, D., Lessmann, E., and Rivera, J. (2009). Adapters in the organization of mast cell signaling. Immunol. Rev. 232, 195-217.
Arend, W. P., Palmer, G., and Gabay, C. (2008). IL-1, IL-18, and IL-33 families of cytokines. Immunol. Rev. 223, 20-38.

Asea, A. (2008). Heat shock proteins and toll-like receptors. Handb. Exp. Pharmacol. 111-127.

Aucher, A., Magdeleine, E., Joly, E., and Hudrisier, D. (2008). Capture of plasma membrane fragments from target cells by trogocytosis requires signaling in T cells but not in B cells. Blood 111, 5621-5628.

Auchincloss, H. Jr., Lee, R., Shea, S., Markowitz, J. S., Grusby, M. J., and Glimcher, L. H. (1993). The role of "indirect" recognition in initiating rejection of skin grafts from major histocompatibility complex class II-deficient mice. Proc. Natl. Acad. Sci. U.S.A. 90, 3373-3377. 
Auchincloss, H. Jr., and Sultan, H. (1996). Antigen processing and presentation in transplantation. Curr. Opin. Immunol. 8, 681-687.

Austyn, J. M., Steinman, R. M., Weinstein, D. E., Granelli-Piperno, A., and Palladino, M. A. (1983). Dendritic cells initiate a two-stage mechanism for $\mathrm{T}$ lymphocyte proliferation. $J$. Exp. Med. 157, 1101-1115.

Austyn, J. M., Weinstein, D. E., and Steinman, R. M. (1988). Clustering with dendritic cells precedes and is essential for T-cell proliferation in a mitogenesis model. Immunology 63 , 691-696.

Bacci, S., Nakamura, T., and Streilein, J. W. (1996). Failed antigen presentation after UVB radiation correlates with modifications of Langerhans cell cytoskeleton. J. Invest. Dermatol. 107, 838-843.

Baker, R. J., Hernandez-Fuentes, M. P., Brookes, P. A., Chaudhry, A. N., Cook, H. T., and Lechler, R. I. (2001). Loss of direct and maintenance of indirect alloresponses in renal allograft recipients: implications for the pathogenesis of chronic allograft nephropathy. J. Immunol. 167, 7199-7206.

Banchereau, J., and Steinman, R. M. (1998). Dendritic cells and the control of immunity. Nature 392, 245-252.

Bani-Hani, A. H., Leslie, J. A., Asanuma, H., Dinarello, C. A., Campbell, M. T., Meldrum, D. R., Zhang, H., Hile, K., and Meldrum, K. K. (2009). IL-18 neutralization ameliorates obstruction-induced epithelialmesenchymal transition and renal fibrosis. Kidney Int. 76, 500-511.

Barnes, P. J. (2011). Pathophysiology of allergic inflammation. Immunol. Rev. 242, 31-50.

Barton, G. M., and Medzhitov, R. (2003). Toll-like receptor signaling pathways. Science 300, 1524-1525.

Beller, D. I., and Unanue, E. R. (1980). IA antigens and antigen-presenting function of thymic macrophages. $J$. Immunol. 124, 1433-1440.

Benichou, G., Takizawa, P. A., Olson, C. A., McMillan, M., and Sercarz, E. E. (1992). Donor major histocompatibility complex (MHC) peptides are presented by recipient MHC molecules during graft rejection. J. Exp. Med. 175, 305-308.

Benichou, G., Valujskikh, A., and Heeger, P. S. (1999). Contributions of direct and indirect $\mathrm{T}$ cell alloreactivity during allograft rejection in mice. J. Immunol. 162, 352-358.

Benichou, G., and Voisin, G. A. (1987). Antibody bipolar bridging: isotypedependent signals given to guinea pig alveolar macrophages by antiMHC alloantibodies. Cell. Immunol. 106, 304-317.

Bertin-Maghit, S., Pang, D., O'Sullivan, B., Best, S., Duggan, E., Paul, S., Thomas, H., Kay, T. W., Harrison, L. C., Steptoe, R., and Thomas, R. (2011). Interleukin-1beta produced in response to islet autoantigen presentation differentiates T-helper 17 cells at the expense of regulatory $\mathrm{T}$ cells: implications for the timing of tolerizing immunotherapy. Diabetes 60, 248-257.

Billingham, R. E., Brent, L., and Medawar, P. B. (1953). Activity acquired tolerance of foreign cells. Nature 172, 603-606.

Biron, C. A., Nguyen, K. B., Pien, G. C., Cousens, L. P., and Salazar-Mather, T. P. (1999). Natural killer cells in antiviral defense: function and regulation by innate cytokines. Annu. Rev. Immunol. 17, 189-220.

Bluestone, J. A. (1996). Costimulation and its role in organ transplantation. Clin. Transplant. 10, 104-109.

Bobr, A., Olvera-Gomez, I., Igyarto, B. Z., Haley, K. M., Hogquist, K. A., and Kaplan, D. H. (2010). Acute ablation of Langerhans cells enhances skin immune responses. J. Immunol. 185, 4724-4728.

Boehm, U., Klamp, T., Groot, M., and Howard, J. C. (1997). Cellular responses to interferon-gamma. Annu. Rev. Immunol. 15, 749-795.

Bourke, E., Bosisio, D., Golay, J., Polentarutti, N., and Mantovani, A. (2003). The toll-like receptor repertoire of human B lymphocytes: inducible and selective expression of TLR9 and TLR10 in normal and transformed cells. Blood 102, 956-963.

Braun, M. Y., Desalle, F., Le Moine, A., Pretolani, M., Matthys, P., Kiss, R., and Goldman, M. (2000). IL-5 and eosinophils mediate the rejection of fully histoincompatible vascularized cardiac allografts: regulatory role of alloreactive $\mathrm{CD} 8(+) \mathrm{T}$ lymphocytes and IFN-gamma. Eur. J. Immunol. 30, 1290-1296.

Brem-Exner, B. G., Sattler, C., Hutchinson, J. A., Koehl, G. E., Kronenberg, K., Farkas, S., Inoue, S., Blank, C., Knechtle, S. J., Schlitt, H. J., FŠndrich, F., and Geissler, E. K. (2008). Macrophages driven to a novel state of activation have anti-inflammatory properties in mice. J. Immunol. 180 , 335-349.

Buonocore, S., Surquin, M., Le Moine, A., Abramowicz, D., Flamand, V., and Goldman, M. (2004). Amplification of T-cell responses by neutrophils: relevance to allograft immunity. Immunol. Lett. 94, 163-166.

Burrell, B. E., Csencsits, K., Lu, G., Grabauskiene, S., and Bishop, D. K. (2008). CD8+ Th17 mediate costimulation blockade-resistant allograft rejection in T-bet-deficient mice. J. Immunol. 181, 3906-3914.

Calderon, B., Suri, A., and Unanue, E. R. (2006). In CD4+ T-cellinduced diabetes, macrophages are the final effector cells that mediate islet beta-cell killing: studies from an acute model. Am. J. Pathol. 169 , 2137-2147.

Capron, M., and Goldman, M. (2001). The eosinophil, a cell with multiple facets. Therapie 56, 371-375.

Caramalho, I., Lopes-Carvalho, T., Ostler, D., Zelenay, S., Haury, M. and Demengeot, J. (2003). Regulatory $\mathrm{T}$ cells selectively express tolllike receptors and are activated by lipopolysaccharide. J. Exp. Med. 197, 403-411.

Carroll, M. C. (1998). The role of complement and complement receptors in induction and regulation of immunity. Annu. Rev. Immunol. 16 545-568.

Cecka, M. (1998). Clinical outcome of renal transplantation. Factors influencing patient and graft survival. Surg. Clin. North Am. 78, 133-148.

Chan, R. K., Ibrahim, S. I., Takahashi, K., Kwon, E., McCormack, M., Ezekowitz, A., Carroll, M. C., Moore, F. D. Jr., and Austen, W. G. Jr. (2006). The differing roles of the classical and mannose-binding lectin complement pathways in the events following skeletal muscle ischemia-reperfusion. J. Immunol. 177, 8080-8085.

Chan, S. Y., DeBruyne, L. A., Goodman, R. E., Eichwald, E. J., and Bishop, D. K. (1995). In vivo depletion of CD8+ $\mathrm{T}$ cells results in Th2 cytokine production and alternate mechanisms of allograft rejection. Transplantation 59, 1155-1161.

Charlton, B., and Lafferty, K. J. (1995). The Th1/Th2 balance in autoimmunity. Curr. Opin. Immunol. 7 , 793-798.

Chen, L., Wang, T., Zhou, P., Ma, L., Yin, D., Shen, J., Molinero, L., Nozaki, T. Phillips, T., Uematsu, S., Akira, S., Wang, C. R., Fairchild, R. L., Alegre, M. L., and Chong, A. (2006). TLR engagement prevents transplantation tolerance. Am. J. Transplant. 6, 2282-2291.

Cohn, L., Whittaker, L., Niu, N., and Homer, R. J. (2002). Cytokine regulation of mucus production in a model of allergic asthma. Novartis Found. Symp. 248, 201-213; discussion 213-220, 277-282.

Daeron, M., Duc, H. T., Kanellopoulos, J., Le Bouteiller, P., Kinsky, R., and Voisin, G. A. (1975). Allogenic mast cell degranulation induced by histocompatibility antibodies: an in vitro model of transplantation anaphylaxis. Cell. Immunol. 20, 133-155.

Daeron, M., Kinsky, R. G., and Voisin, G. A. (1972). In vitro anaphylactic degranulation of mast cells by transplantation antibodies in mice. C.R. Hebd. Seances Acad. Sci. Ser. D Sci. Nat. 275, 2571-2573.

Daeron, M., Prouvost-Danon, A., and Voisin, G. A. (1980). Mast cell membrane antigens and $\mathrm{Fc}$ receptors in anaphylaxis. II. Functionally distinct receptors for IgG and for IgE on mouse mast cells. Cell. Immunol. 49 , 178-189.

Daeron, M., and Voisin, G. A. (1978) $\mathrm{H}-2$ antigens, on mast cell membrane, as target antigens for anaphylactic degranulation. Cell. Immunol. 37, 467-472.

Daeron, M., and Voisin, G. A. (1979). Mast cell membrane antigens and Fc receptors in anaphylaxis. I. Products of the major histocompatibility complex involved in alloantibody-induced mast cell activation. Immunology 38, 447-458.

Dalchau, R., Fangmann, J., and Fabre, J. W. (1992). Allorecognition of isolated, denatured chains of class I and class II major histocompatibility complex molecules. Evidence for an important role for indirect allorecognition in transplantation. Eur. J. Immunol. 22, 669-677.

Dana, M. R., Dai, R., Zhu, S., Yamada, J., and Streilein, J. W. (1998). Interleukin-1 receptor antagonist suppresses Langerhans cell activity and promotes ocular immune privilege. Invest. Ophthalmol. Vis. Sci. 39, 70-77.

Dana, M. R., Yamada, J., and Streilein, J. W. (1997). Topical interleukin 1 receptor antagonist promotes corneal transplant survival. Transplantation 63, 1501-1507.

Davies, M. J., Gordon, J. L., Gearing, A. J., Pigott, R., Woolf, N., Katz, D. and Kyriakopoulos, A. (1993). The expression of the adhesion molecules ICAM-1, VCAM-1, PECAM, and E-selectin in human atherosclerosis. J. Pathol. 171, 223-229.

de Vries, V. C., Elgueta, R., Lee, D. M., and Noelle, R. J. (2010). Mast cell protease 6 is required for allograft tolerance. Transplant. Proc. 42, 2759-2762. 
de Vries, V. C., and Noelle, R. J. (2010). Mast cell mediators in tolerance. Curr. Opin. Immunol. 22, 643-648.

de Vries, V. C., Wasiuk, A., Bennett, K. A., Benson, M. J., Elgueta, R., Waldschmidt, T. J., and Noelle, R. J. (2009a). Mast cell degranulation breaks peripheral tolerance. Am. J. Transplant. 9, 2270-2280.

de Vries, V. C., Pino-Lagos, K., Elgueta, R., and Noelle, R. J. (2009b). The enigmatic role of mast cells in dominant tolerance. Curr. Opin. Organ Transplant. 14, 332-337.

Dekaris, I. J., Yamada, J. J., Streilein, W. J., and Dana, R. M. (1999). Effect of topical interleukin-1 receptor antagonist (IL-1ra) on corneal allograft survival in presensitized hosts. Curr. Eye Res. 19, 456-459.

Demir, Y., Chen, Y., Metz, C., Renz, H., and Heeger, P. S. (2003). Cardiac allograft rejection in the absence of macrophage migration inhibitory factor. Transplantation 76, 244-247.

DeVries, M. E., Hosiawa, K. A., Cameron, C. M., Bosinger, S. E., Persad, D., Kelvin, A. A., Coombs, J. C., Wang, H., Zhong, R., Cameron, M. J., and Kelvin, D. J. (2003). The role of chemokines and chemokine receptors in alloantigen-independent and alloantigen-dependent transplantation injury. Semin. Immunol. 15, 33-48.

Dhodapkar, M. V., Steinman, R. M., Krasovsky, J., Munz, C., and Bhardwaj, N. (2001). Antigen-specific inhibition of effector $\mathrm{T}$ cell function in humans after injection of immature dendritic cells. J. Exp. Med. 193, 233-238.

Dinarello, C. A. (2009). Interleukinlbeta and the autoinflammatory diseases. N. Engl. J. Med. 360, 2467-2470.

Dinarello, C. A. (2011a). Interleukin-1 in the pathogenesis and treatment of inflammatory diseases. Blood 117 , 3720-3732.

Dinarello, C. A. (2011b). A clinical perspective of IL-1beta as the gatekeeper of inflammation. Eur. J. Immunol. 41, 1203-1217.

Dinarello, C. A. (2011c). Blocking interleukin-1beta in acute and chronic autoinflammatory diseases. J. Intern. Med. 269, 16-28.

Dong, Q., Louahed, J., Vink, A., Sullivan, C. D., Messler, C. J., Zhou, Y., Haczku, A., Huaux, F., Arras, M., Holroyd, K. J., Renauld, J. C., Levitt, R. C., and Nicolaides, N. C. (1999). IL-9 induces chemokine expression in lung epithelial cells and baseline airway eosinophilia in transgenic mice. Eur. J. Immunol. 29, 2130-2139.
Elmaagacli, A. H., Koldehoff, M., Hindahl, H., Steckel, N. K., Trenschel, R., Peceny, R., Ottinger, H., Rath, P. M., Ross, R. S., Roggendorf, M., Grosse-Wilde, H., and Beelen, D. W. (2006). Mutations in innate immune system NOD2/CARD 15 and TLR4 (Thr399Ile) genes influence the risk for severe acute graft-versushost disease in patients who underwent an allogeneic transplantation. Transplantation 81, 247-254.

El-Sawy, T., Belperio, J. A., Strieter, R. M., Remick, D. G., and Fairchild, R. L. (2005). Inhibition of polymorphonuclear leukocyte-mediated graft damage synergizes with shortterm costimulatory blockade to prevent cardiac allograft rejection. Circulation 112, 320-331.

Eppinger, M. J., Deeb, G. M., Bolling, S. F., and Ward, P. A. (1997). Mediators of ischemia-reperfusion injury of rat lung. Am. J. Pathol. 150, 1773-1784.

Fangmann, J., Dalchau, R., and Fabre, J. W. (1992). Rejection of skin allografts by indirect allorecognition of donor class I major histocompatibility complex peptides. J. Exp. Med. 175, 1521-1529.

Fangmann, J., Dalchau, R., and Fabre, J. W. (1993). Rejection of skin allografts by indirect allorecognition of donor class I major histocompatibility complex peptides. Transplant. Proc. 25, 183-184.

Farrar, C. A., Zhou, W., Lin, T., and Sacks, S. H. (2006). Local extravascular pool of C3 is a determinant of postischemic acute renal failure. FASEB J. 20, 217-226.

Faure, E., Equils, O., Sieling, P. A., Thomas, L., Zhang, F. X., Kirschning, C. J., Polentarutti, N., Muzio, M., and Arditi, M. (2000). Bacterial lipopolysaccharide activates NFkappaB through toll-like receptor 4 (TLR-4) in cultured human dermal endothelial cells. Differential expression of TLR- 4 and TLR-2 in endothelial cells. J. Biol. Chem. 275, 11058-11063.

Fearon, D. T., and Carroll, M. C. (2000). Regulation of B lymphocyte responses to foreign and selfantigens by the CD19/CD21 complex. Annu. Rev. Immunol. 18, 393-422.

Fedoseyeva, E. V., Kishimoto, K., Rolls, H. K., Illigens, B. M., Dong, V. M., Valujskikh, A., Heeger, P. S., Sayegh, M. H., and Benichou, G. (2002). Modulation of tissuespecific immune response to cardiac myosin can prolong survival of allogeneic heart transplants. J. Immunol. $169,1168-1174$.
Fischereder, M., Luckow, B., Hocher, B. Wüthrich, R. P., Rothenpieler, U. Schneeberger, H., Panzer, U., Stahl, R. A., Hauser, I. A., Budde, K., Neumayer, H., Krämer, B. K., Land W., and Schlöndorff, D. (2001). CC chemokine receptor 5 and renaltransplant survival. Lancet 357, 1758-1761.

Forsthuber, T., Yip, H. C., and Lehmann, P. V. (1996). Induction of TH1 and TH2 immunity in neonatal mice. Science 271, 1728-1730.

Foucras, G., Coudert, J. D., Coureau, C., and Guéry, J. C. (2000). Dendritic cells prime in vivo alloreactive CD4 $\mathrm{T}$ lymphocytes toward type 2 cytokine- and TGF-betaproducing cells in the absence of CD8 T cell activation. J. Immunol. 165, 4994-5003.

Frantz, S., Kelly, R. A., and Bourcier, T. (2001). Role of TLR-2 in the activation of nuclear factor kappaB by oxidative stress in cardiac myocytes. J. Biol. Chem. 276, 5197-5203.

Frantz, S., Kobzik, L., Kim, Y. D., Fukazawa, R., Medzhitov, R., Lee, R. T., and Kelly, R. A. (1999). Toll4 (TLR4) expression in cardiac myocytes in normal and failing myocardium. J. Clin. Invest. 104 271-280.

Fu, F., Li, Y., Qian, S., Lu, L., Chambers, F., Starzl, T. E., Fung, J. J., and Thomson, A. W. (1996). Costimulatory molecule-deficient dendritic cell progenitors (MHC class II+, CD80dim, CD86-) prolong cardiac allograft survival in nonimmunosuppressed recipients. Transplantation 62, 659-665.

Fukuyama, S., Yoshino, I., Yamaguchi, M., Osoegawa, A., Kameyama, T., Tagawa, T., and Maehara, Y. (2005). Blockage of the macrophage migration inhibitory factor expression by short interference RNA inhibited the rejection of an allogeneic tracheal graft. Transpl. Int. 18, 1203-1209.

Gabay, C., Lamacchia, C., and Palmer, G. (2010). IL-1 pathways in inflammation and human diseases. Nat. Rev Rheumatol. 6, 232-241.

Gao, W., Faia, K. L., Csizmadia, V., Smiley, S. T., Soler, D., King, J. A., Danoff, T. M., and Hancock, W. W. (2001). Beneficial effects of targeting CCR5 in allograft recipients. Transplantation 72, 1199-1205.

Gao, W., Topham, P. S., King, J. A., Smiley, S. T., Csizmadia, V., Lu, B., Gerard, C. J., and Hancock, W. W. (2000). Targeting of the chemokine receptor CCR1 suppresses development of acute and chronic cardiac allograft rejection. J. Clin. Invest. $105,35-44$.
Geissmann, F., Manz, M. G., Jung, S., Sieweke, M. H., Merad, M., and Ley, K. (2010). Development of monocytes, macrophages, and dendritic cells. Science 327, 656-661.

Goldman, M., Le Moine, A., Braun, M., Flamand, V., and Abramowicz, D. (2001). A role for eosinophils in transplant rejection. Trends Immunol. 22, 247-251.

Goldstein, D. R. (2011). Inflammation and transplantation tolerance. Semin. Immunopathol. 33, 111-115.

Goldstein, D. R., Tesar, B. M., Akira, S., and Lakkis, F. G. (2003). Critical role of the toll-like receptor signal adaptor protein $\mathrm{MyD} 88$ in acute allograft rejection. J. Clin. Invest. 111, 1571-1578

Goriely, S., Molle, C., Nguyen, M., Albarani, V., Haddou, N. O., Lin, R., De Wit, D., Flamand, V., Willems, F., and Goldman, M. (2006). Interferon regulatory factor 3 is involved in Toll-like receptor 4 (TLR4)- and TLR3-induced IL-12p35 gene activation. Blood 107, 1078-1084.

Hamerman, J. A., Ogasawara, K., and Lanier, L. L. (2005). NK cells in innate immunity. Curr. Opin. Immunol. 17, 29-35.

Hancock, W. W., Gao, W., Faia, K. L., and Csizmadia, V. (2000a). Chemokines and their receptors in allograft rejection. Curr. Opin. Immunol. 12, 511-516.

Hancock, W. W., Lu, B., Gao, W., Csizmadia, V., Faia, K., King, J. A., Smiley, S. T., Ling, M., Gerard, N. P., and Gerard, C. (2000b). Requirement of the chemokine receptor CXCR3 for acute allograft rejection. J. Exp. Med. 192, 1515-1520.

Hancock, W. W., Sayegh, M. H., Kwok, C. A., Weiner, H. L., and Carpenter, C. B. (1993). Oral, but not intravenous, alloantigen prevents accelerated allograft rejection by selective intragraft Th2 cell activation. Transplantation 55, 1112-1118.

Harada, K., Ohira, S., Isse, K., Ozaki, S., Zen, Y., Sato, Y., and Nakanuma, Y. (2003). Lipopolysaccharide activates nuclear factor-kappaB through toll-like receptors and related molecules in cultured biliary epithelial cells. Lab. Invest. 83, 1657-1667.

Hart, O. M., Athie-Morales, V., O'Connor, G. M., and Gardiner, C. M. (2005). TLR7/8-mediated activation of human NK cells results in accessory cell-dependent IFNgamma production. J. Immunol. 175, 1636-1642.

Hayashi, F., Means, T. K., and Luster, A. D. (2003). Toll-like receptors stimulate human neutrophil function. Blood 102, 2660-2669. 
Hayry, P., Isoniemi, H., Yilmaz, S., Mennander, A., Lemstrom, K., RaisanenSokolowski, A., Koskinen, P., Ustinov, J., Lautenschlager, I., Taskinen, E., Krogerus, L., Aho, P., and Paavonen, T. (1993). Chronic allograft rejection. Immunol. Rev. 134, 33-81.

Herrera, O. B., Golshayan, D., Tibbott, R., Salcido Ochoa, F., James, M. J., Marelli-Berg, F. M., and Lechler, R. I. (2004). A novel pathway of alloantigen presentation by dendritic cells. J. Immunol. 173, 4828-4837.

Holan, V. (1988). Modulation of allotransplantation tolerance induction by interleukin-1 and interleukin-2. J. Immunogenet. 15, 331-337.

Honjo, K., Xu, X. Y., and Bucy, R. P. (2000). Heterogeneity of $\mathrm{T}$ cell clones specific for a single indirect alloantigenic epitope $(\mathrm{I}-\mathrm{Ab} / \mathrm{H}-$ $2 \mathrm{Kd} 54-68)$ that mediate transplant rejection. Transplantation 70 , 1516-1524.

Hornung, V., Rothenfusser, S., Britsch, S., Krug, A., Jahrsdšrfer, B., Giese, T., Endres, S., and Hartmann, G. (2002). Quantitative expression of toll-like receptor 1-10 mRNA in cellular subsets of human peripheral blood mononuclear cells and sensitivity to CpG oligodeoxynucleotides. J. Immunol. 168, 4531-4537.

Hosenpud, J. D., Mauck, K. A., and Hogan, K. B. (1997). Cardiac allograft vasculopathy: IgM antibody responses to donor-specific vascular endothelium. Transplantation 63 , 1602-1606.

Hou, G., Valujskikh, A., Bayer, J., Stavitsky, A. B., Metz, C., and Heeger, P. S. (2001). In vivo blockade of macrophage migration inhibitory factor prevents skin graft destruction after indirect allorecognition. Transplantation 72, 1890-1897.

Huang, J., Kim, L. J., Mealey, R., Marsh, H. C., Zhang, Y., Tenner, A. J., Connolly, E. S., and Pinsky, D. J. (1999). Neuronal protection in stroke by an sLex-glycosylated complement inhibitory protein. Science 285, 595-599.

Hutchinson, J. A., Riquelme, P., Sawitzki, B., Tomiuk, S., Miqueu, P., Zuhayra, M., Oberg, H. H., Pascher, A., Lutzen, U., Janssen, U., Broichhausen, C., Renders, L., Thaiss, F., Scheuermann, E., Henze, E., Volk, H. D., Chatenoud, L., Lechler, R. I., Wood, K. J., Kabelitz, D., Schlitt, H. J., Geissler, E. K., and Fandrich, F. (2011). Cutting Edge: immunological consequences and trafficking of human regulatory macrophages administered to renal transplant recipients. J. Immunol. 187, 2072-2078.

Ide, K., Wang, H., Tahara, H., Liu, J., Wang, X., Asahara, T., Sykes, M., Yang, Y. G., and Ohdan, H. (2007). Role for CD47-SIRPalpha signaling in xenograft rejection by macrophages. Proc. Natl. Acad. Sci. U.S.A. 104, 5062-5066.

Igyarto, B. Z., Haley, K., Ortner, D., Bobr, A., Gerami-Nejad, M., Edelson, B. T., Zurawski, S. M., Malissen, B., Zurawski, G., Berman, J., and Kaplan, D. H. (2011) Skinresident murine dendritic cell subsets promote distinct and opposing antigen-specific $\mathrm{T}$ helper cell responses. Immunity 35, 260-272.

Igyarto, B. Z., and Kaplan, D. H. (2010). The evolving function of Langerhans cells in adaptive skin immunity. Immunol. Cell Biol. 88, 361-365.

Ikai, M., Itoh, M., Joh, T., Yokoyama, Y., Okada, N., and Okada, H. (1996). Complement plays an essential role in shock following intestinal ischaemia in rats. Clin. Exp. Immunol. 106, 156-159.

Illigens, B. M., Yamada, A., Anosova, N., Dong, V. M., Sayegh, M. H., and Benichou, G. (2009). Dual effects of the alloresponse by Th1 and Th2 cells on acute and chronic rejection of allotransplants. Eur. J. Immunol. 39, 3000-3009.

Illigens, B. M., Yamada, A., Fedoseyeva, E. V., Anosova, N., Boisgerault, F., Valujskikh, A., Heeger, P. S., Sayegh, M. H., Boehm, B., and Benichou, G. (2002). The relative contribution of direct and indirect antigen recognition pathways to the alloresponse and graft rejection depends upon the nature of the transplant. Hum. Immunol. 63, 912-925.

Ito, T., Yang, M., Wang, Y. H., Lande, R., Gregorio, J., Perng, O. A., Qin, X. F., Liu, Y. J., and Gilliet, M. (2007). Plasmacytoid dendritic cells prime IL-10-producing $\mathrm{T}$ regulatory cells by inducible costimulator ligand. $J$. Exp. Med. 204, 105-115.

Ivanov, S., Dragoi, A. M., Wang, X., Dallacosta, C., Louten, J., Musco, G., Sitia, G., Yap, G. S., Wan, Y., Biron, C. A., Bianchi, M. E., Wang, H., and Chu, W. M. (2007). A novel role for HMGB1 in TLR9-mediated inflammatory responses to $\mathrm{CpG}$ DNA. Blood 110, 1970-1981.

Iwasaki, A., and Medzhitov, R. (2004). Toll-like receptor control of the adaptive immune responses. Nat. Immunol. 5, 987-995.

Jaeschke, H., Farhood, A., and Smith, C. W. (1990). Neutrophils contribute to ischemia/reperfusion injury in rat liver in vivo. FASEB J. 4, 3355-3359.
Javeed, A., and Zhao, Y. (2008). Macrophage-migration inhibitory factor: role in inflammatory diseases and graft rejection. Inflamm. Res. $57,45-50$.

Joly, E., and Hudrisier, D. (2003). What is trogocytosis and what is its purpose? Nat. Immunol. 4, 815.

Jones, N. D., Brook, M. O., CarvalhoGaspar, M., Luo, S., and Wood, K. J. (2010) Regulatory T cells can prevent memory CD8+ T-cell-mediated rejection following polymorphonuclear cell depletion. Eur. J. Immunol. 40, 3107-3116.

Kamari, Y., Shaish, A., Shemesh, S., Vax, E., Grosskopf, I., Dotan, S., White, M., Voronov, E., Dinarello, C. A., Apte, R. N., and Harats, D. (2011). Reduced atherosclerosis and inflammatory cytokines in apolipoprotein-E-deficient mice lacking bone marrow-derived interleukin-1alpha. Biochem. Biophys. Res. Commun. 405, 197-203.

Kang, Y. H., Tan, L. A., Carroll, M. V., Gentle, M. E., and Sim, R. B. (2009). Target pattern recognition by complement proteins of the classical and alternative pathways. $A d v$. Exp. Med. Biol. 653, 117-128.

Kanzler, H., Barrat, F. J., Hessel, E. M., and Coffman, R. L. (2007). Therapeutic targeting of innate immunity with Toll-like receptor agonists and antagonists. Nat. Med. 13, 552-559.

Karlhofer, F. M., Ribaudo, R. K., and Yokoyama, W. M. (1992). MHC class I alloantigen specificity of Ly-49+ IL-2-activated natural killer cells. Nature 358, 66-70.

Karlhofer, F. M., Ribaudo, R. K., and Yokoyama, W. M. (2006). MHC Class I alloantigen specificity of Ly-49+ IL-2-activated natural killer cells. Nature 358:66-70, 1992. J. Immunol. 177, 5761-5765.

Karre, K., Ljunggren, H. G., Piontek, G., and Kiessling, R. (1986). Selective rejection of $\mathrm{H}$-2-deficient lymphoma variants suggests alternative immune defence strategy. Nature 319, 675-678.

Kay, A. B., Barata, L., Meng, Q., Durham, S. R., and Ying, S. (1997). Eosinophils and eosinophilassociated cytokines in allergic inflammation. Int. Arch. Allergy Immunol. 113, 196-199.

Kean, L. S., Gangappa, S., Pearson, T. C., and Larsen, C. P. (2006). Transplant tolerance in non-human primates: progress, current challenges and unmet needs. Am. J. Transplant. 6, 884-893.
Kim, J., Chang, C. K., Hayden, T., Liu, F. C., Benjamin, J., Hamerman, J. A., Lanier, L. L., and Kang, S. M. (2007). The activating immunoreceptor NKG2D and its ligands are involved in allograft transplant rejection. J. Immunol. 179, 6416-6420.

Kishimoto, K., Dong, V. M., Issazadeh, S., Fedoseyeva, E. V., Waaga, A. M., Yamada, A., Sho, M., Benichou, G., Auchincloss, H. Jr., Grusby, M. J., Khoury, S. J., and Sayegh, M. H. (2000). The role of CD154-CD40 versus $\mathrm{CD} 28$ - B7 costimulatory pathways in regulating allogeneic Th1 and Th2 responses in vivo. J. Clin. Invest. 106, 63-72.

Kitchens, W. H., Chase, C. M., Uehara, S., Cornell, L. D., Colvin, R. B., Russell, P. S., and Madsen, J. C. (2007). Macrophage depletion suppresses cardiac allograft vasculopathy in mice. Am. J. Transplant. 7, 2675-2682.

Kitchens, W. H., Uehara, S., Chase, C. M., Colvin, R. B., Russell, P. S., and Madsen, J. C. (2006). The changing role of natural killer cells in solid organ rejection and tolerance. Transplantation 81, 811-817.

Koksoy, S., Kakoulidis, T. P., and Shirwan, H. (2004). Chronic heart allograft rejection in rats demonstrates a dynamic interplay between IFN-gamma and IL-10 producing T cells. Transpl. Immunol. 13, 201-209.

Koyama, I., Nadazdin, O., Boskovic, S., Ochiai, T., Smith, R. N., Sykes, M., Sogawa, H., Murakami, T., Strom, T. B., Colvin, R. B., Sachs, D. H., Benichou, G., Cosimi, A. B., and Kawai, T. (2007). Depletion of CD8 memory $\mathrm{T}$ cells for induction of tolerance of a previously transplanted kidney allograft. Am. J. Transplant. 7, 1055-1061.

Kurimoto, I., Kitazawa, T., and Streilein, J. W. (2000). Studies of delayed systemic effects of ultraviolet $B$ radiation (UVR) on the induction of contact hypersensitivity, 2. Evidence that interleukin-10 from UVR-treated epidermis is the critical mediator. Immunology 99, 134-140.

Lalli, P. N., Strainic, M. G., Yang, M., Lin, F., Medof, M. E., and Heeger, P. S. (2008). Locally produced C5a binds to $\mathrm{T}$ cell-expressed $\mathrm{C} 5 \mathrm{aR}$ to enhance effector T-cell expansion by limiting antigen-induced apoptosis. Blood 112, 1759-1766.

Lanzavecchia, A., and Sallusto, F. (2000). Dynamics of T lymphocyte responses: intermediates, effectors, and memory cells. Science 290 , 92-97. 
Lanzavecchia, A., and Sallusto, F. (2001). Antigen decoding by T lymphocytes: from synapses to fate determination. Nat. Immunol. 2, 487-492.

LaRosa, D. F., Rahman, A. H., and Turka, L. A. (2007). The innate immune system in allograft rejection and tolerance. J. Immunol. 178, 7503-7509.

Larsen, C. P., and Austyn, J. M. (1991). Langerhans cells migrate out of skin grafts and cultured skin: a model in which to study the mediators of dendritic leukocyte migration. Transplant. Proc. 23, 117-119.

Larsen, C. P., Austyn, J. M., and Morris, P. J. (1990a). The role of graft-derived dendritic leukocytes in the rejection of vascularized organ allografts. Recent findings on the migration and function of dendritic leukocytes after transplantation. Ann. Surg. 212, 308-315; discussion 316-307.

Larsen, C. P., Morris, P. J., and Austyn, J. M. (1990b). Migration of dendritic leukocytes from cardiac allografts into host spleens. A novel pathway for initiation of rejection. J. Exp. Med. 171, 307-314.

Larsen, C. P., Morris, P. J., and Austyn, J. M. (1990c). Donor dendritic leukocytes migrate from cardiac allografts into recipients' spleens. Transplant. Proc. 22, 1943-1944.

Larsen, C. P., Steinman, R. M., WitmerPack, M., Hankins, D. F., Morris, P. J., and Austyn, J. M. (1990d). Migration and maturation of Langerhans cells in skin transplants and explants. J. Exp. Med. 172, 1483-1493.

Le Bouteiller, P., Daeron, M., Duc, H. T., Righenzi, S., and Voisin, G. A. (1976). An ultrastructural study of two different responses of mouse mast cells to transplantation antibodies directed against the same transplantation antigens. Eur. J. Immunol. 6, 326-332.

Le Moine, A., Surquin, M., Demoor, F. X., Noël, J. C., Nahori, M. A., Pretolani, M., Flamand, V., Braun, M. Y., Goldman, M., and Abramowicz, D. (1999). IL-5 mediates eosinophilic rejection of MHC class II-disparate skin allografts in mice. J. Immunol. 163, 3778-3784.

Lechler, R. I., and Batchelor, J. R. (1982). Restoration of immunogenicity to passenger cell-depleted kidney allografts by the addition of donor strain dendritic cells. J. Exp. Med. 155, 31-41.

Lechler, R. I., Lombardi, G., Batchelor, J. R., Reinsmoen, N., and Bach, F. H. (1990). The molecular basis of alloreactivity. Immunol. Today 11, 83-88.
Lee, R. S., Grusby, M. J., Glimcher, L. H., Winn, H. J., and Auchincloss, H. Jr. (1994). Indirect recognition by helper cells can induce donor-specific cytotoxic T lymphocytes in vivo. J. Exp. Med. 179, 865-872.

Lee, R. S., Grusby, M. J., Laufer, T. M., Colvin, R., Glimcher, L. H., and Auchincloss, H. Jr. (1997). CD8+ effector cells responding to residual class I antigens, with help from $\mathrm{CD} 4+$ cells stimulated indirectly, cause rejection of "major histocompatibility complex-deficient" skin grafts. Transplantation 63, 1123-1133.

Lee, R. S., Yamada, K., Houser, S. L., Womer, K. L., Maloney, M. E., Rose, H. S., Sayegh, M. H., and Madsen, J. C. (2001). Indirect recognition of allopeptides promotes the development of cardiac allograft vasculopathy. Proc. Natl. Acad. Sci. U.S.A. 98, 3276-3281.

Lewis, E. C., Mizrahi, M., Toledano, M., Defelice, N., Wright, J. L., Churg, A., Shapiro, L., and Dinarello, C. A. (2008). Alphal-antitrypsin monotherapy induces immune tolerance during islet allograft transplantation in mice. Proc. Natl. Acad. Sci. U.S.A. 105, 16236-16241.

Li, K., Sacks, S. H., and Zhou, W. (2007). The relative importance of local and systemic complement production in ischaemia, transplantation and other pathologies. Mol. Immunol. 44, 3866-3874.

Li, X. C. (2010). The significance of non-T-cell pathways in graft rejection: implications for transplant tolerance. Transplantation 90, 1043-1047.

Liu, H., Komai-Koma, M., Xu, D., and Liew, F. Y. (2006). Toll-like receptor 2 signaling modulates the functions of CD4+ CD25+ regulatory $\mathrm{T}$ cells. Proc. Natl. Acad. Sci. U.S.A. 103, 7048-7053.

Liu, K., Victora, G. D., Schwickert, T. A., Guermonprez, P., Meredith, M. M., Yao, K., Chu, F. F., Randolph, G. J., Rudensky, A. Y., and Nussenzweig, M. (2009). In vivo analysis of dendritic cell development and homeostasis. Science 324, 392-397.

Liu, Y. J. (2005). IPC: professional type 1 interferon-producing cells and plasmacytoid dendritic cell precursors. Annu. Rev. Immunol. 23, 275-306.

Liu, Z., Colovai, A. I., Tugulea, S., Reed, E. F., Fisher, P. E., Mancini, D., Rose, E. A., Cortesini, R., Michler, R. E., and Suciu-Foca, N. (1996). Indirect recognition of donor HLA-DR peptides in organ allograft rejection. $J$. Clin. Invest. 98, 1150-1157.
Ljunggren, H. G., and Karre, K. (1990). In search of the 'missing self': MHC molecules and NK cell recognition. Immunol. Today 11, 237-244.

Ljunggren, H. G., Sturmhofel, K. Wolpert, E., Hammerling, G. J., and Karre, K. (1990). Transfection of beta 2 -microglobulin restores IFNmediated protection from natural killer cell lysis in YAC-1 lymphoma variants. J. Immunol. 145, 380-386.

Lu, C. Y., Peters, E., and Unanue, E. R. (1981). Ia-bearing macrophages in athymic mice: antigen presentation and regulation. J. Immunol. 126 , 2496-2498.

Lu, C. Y., and Unanue, E. R. (1982). Ontogeny of murine macrophages: functions related to antigen presentation. Infect. Immun. 36, 169-175.

Lu, L., and Thomson, A. W. (2002). Manipulation of dendritic cells for tolerance induction in transplantation and autoimmune disease. Transplantation 73, S19-S22.

Lu, L. F., Lind, E. F., Gondek, D. C., Bennett, K. A., Gleeson, M. W., PinoLagos, K., Scott, Z. A., Coyle, A. J., Reed, J. L., Van Snick, J., Strom, T. B. Zheng, X. X., and Noelle, R. J. (2006). Mast cells are essential intermediaries in regulatory $\mathrm{T}$-cell tolerance. Nature 442, 997-1002.

Maier, S., Tertilt, C., Chambron, N., Gerauer, K., Huser, N., Heidecke, C. D., and Pfeffer, K. (2001). Inhibition of natural killer cells results in acceptance of cardiac allografts in CD28-/- mice. Nat. Med. 7, 557-562.

Marone, G., Patella, V., de Crescenzo, G., Granata, F., and Calabrese, C. (2000). Immunological interactions between human eosinophils and cardiac mast cells. Chem. Immunol. 76, 118-133.

Marsh, J. E., Farmer, C. K., Jurcevic, S., Wang, Y., Carroll, M. C., and Sacks, S. H. (2001). The allogeneic T and B cell response is strongly dependent on complement components $\mathrm{C} 3$ and C4. Transplantation 72, 1310-1318.

Martinez, O. M., Ascher, N. L., Ferrell, L., Villanueva, J., Lake, J., Roberts, J. P., and Krams, S. M. (1993). Evidence for a nonclassical pathway of graft rejection involving interleukin 5 and eosinophils. Transplantation 55, 909-918.

Martin-Fontecha, A., Thomsen, L. L. Brett, S., Gerard, C., Lipp, M., Lanzavecchia, A., and Sallusto, F. (2004) Induced recruitment of NK cells to lymph nodes provides IFN-gamma for $\mathrm{T}(\mathrm{H}) 1$ priming. Nat. Immunol. 5, 1260-1265.

Masli, S., Turpie, B., and Streilein, J. W. (2006). Thrombospondin orchestrates the tolerance-promoting properties of TGFbeta-treated antigen-presenting cells. Int. Immunol. 18, 689-699.

Matesic, D., Valujskikh, A., Pearlman, E. Higgins, A. W., Gilliam, A. C., and Heeger, P. S. (1998). Type 2 immune deviation has differential effects on alloreactive CD4+ and CD8+ T cells. J. Immunol. 161, 5236-5244.

Matta, B. M., Castellaneta, A., and Thomson, A. W. (2010). Tolerogenic plasmacytoid DC, . Eur. J. Immunol. 40, 2667-2676.

McCurdy, J. D., Lin, T. J., and Marshall, J. S. (2001). Toll-like receptor 4mediated activation of murine mast cells. J. Leukoc. Biol. 70, 977-984.

McNerney, M. E., Lee, K. M., Zhou, P., Molinero, L., Mashayekhi, M., Guzior, D., Sattar, H., Kuppireddi, S., Wang, C. R., Kumar, V., and Alegre, M. L. (2006). Role of natural killer cell subsets in cardiac allograft rejection. Am. J. Transplant. 6, 505-513.

Medzhitov, R. (2001). Toll-like receptors and innate immunity. Nat. Rev. Immunol. 1, 135-145.

Medzhitov, R., and Janeway, C. A. (2002). Decoding the patterns of self and nonself by the innate immune system. Science 296, 298-300.

Mempel, M., Voelcker, V., Kšllisch, G., Plank, C., Rad, R., Gerhard, M., Schnopp, C., Fraunberger, P., Walli, A. K., Ring, J., Abeck, D., and Ollert, M. (2003). Toll-like receptor expression in human keratinocytes: nuclear factor kappaB controlled gene activation by Staphylococcus aureus is toll-like receptor 2 but not toll-like receptor 4 or platelet activating factor receptor dependent. $J$ Invest. Dermatol. 121, 1389-1396.

Mhoyan, A., Wu, G. D., Kakoulidis, T. P., Que, X., Yolcu, E. S., Cramer, D. V., and Shirwan, H. (2003). Predominant expression of the Th2 response in chronic cardiac allograft rejection. Transpl. Int. 16, 464-473.

Miller, D. M., Thornley, T. B., Greiner, D. L., and Rossini, A. A. (2008). Viral infection: a potent barrier to transplantation tolerance. Clin. Dev. Immunol. 2008, 742810.

Molle, C., Nguyen, M., Flamand, V., Renneson, J., Trottein, F., De Wit, D., Willems, F., Goldman, M., and Goriely, S. (2007). IL-27 synthesis induced by TLR ligation critically depends on IFN regulatory factor 3 . J. Immunol. 178, 7607-7615.

Mollen, K. P., Anand, R. J., Tsung, A., Prince, J. M., Levy, R. M., and Billiar, T. R. (2006). Emerging paradigm: toll-like receptor 4-sentinel for the detection of tissue damage. Shock 26, 430-437. 
Morelli, A. E., and Thomson, A. W. (2003). Dendritic cells: regulators of alloimmunity and opportunities for tolerance induction. Immunol. Rev. 196, 125-146.

Morita, K., Miura, M., Paolone, D. R., Engeman, T. M., Kapoor, A., Remick, D. G., and Fairchild, R. L. (2001). Early chemokine cascades in murine cardiac grafts regulate $\mathrm{T}$ cell recruitment and progression of acute allograft rejection. J. Immunol. 167, 2979-2984.

Murphy, S. P., Porrett, P. M., and Turka, L. A. (2011). Innate immunity in transplant tolerance and rejection. Immunol. Rev. 241, 39-48.

Muzio, M., Bosisio, D., Polentarutti, N., D’Amico, G., Stoppacciaro, A., Mancinelli, R., van't Veer, C., PentonRol, G., Ruco, L. P., Allavena, P., and Mantovani, A. (2000). Differential expression and regulation of toll-like receptors (TLR) in human leukocytes: selective expression of TLR3 in dendritic cells. J. Immunol. 164, 5998-6004.

Nadazdin, O., Boskovic, S., Murakami, T., O'Connor, D. H., Wiseman, R. W., Karl, J. A., Tuscher, J. J., Sachs, D. H., Madsen, J. C., Tocco, G., Kawai, T., Cosimi, A. B., and Benichou, G. (2010). Phenotype, distribution and alloreactive properties of memory $\mathrm{T}$ cells from cynomolgus monkeys. Am. J. Transplant. 10, 1375-1384.

Nadazdin, O., Boskovic, S., Murakami, T., Tocco, G., Smith, R. N., Colvin, R. B., Sachs, D. H., Allan, J., Madsen, J. C., Kawai, T., Cosimi, A. B., and Benichou, G. (2011). Host alloreactive memory $\mathrm{T}$ cells influence tolerance to kidney allografts in nonhuman primates. Sci. Transl. Med. 3, 86ra51.

Nagase, H., Okugawa, S., Ota, Y., Yamaguchi, M., Tomizawa, H., Matsushima, K., Ohta, K., Yamamoto, K., and Hirai, K. (2003). Expression and function of Toll-like receptors in eosinophils: activation by Toll-like receptor 7 ligand. J. Immunol. 171, 3977-3982.

Najafian, N., Salama, A. D., Fedoseyeva, E. V., Benichou, G., and Sayegh, M. H. (2002). Enzyme-linked immunosorbent spot assay analysis of peripheral blood lymphocyte reactivity to donor HLA-DR peptides: potential novel assay for prediction of outcomes for renal transplant recipients. J. Am. Soc. Nephrol. 13, 252-259.

Naughton, M. A., Botto, M., Carter, M. J., Alexander, G. J., Goldman, J. M., and Walport, M. J. (1996). Extrahepatic secreted complement
C3 contributes to circulating C3 levels in humans. J. Immunol. 156, 3051-3056.

Netea, M. G., Simon, A., van de Veerdonk, F., Kullberg, B. J., Van der Meer, J. W., and Joosten, L. A. (2010). IL-1beta processing in host defense: beyond the inflammasomes. PLoS Pathog. 6, el000661. doi:10.1371/journal.ppat.1000661

Noble, A., Zhao, Z. S., and Cantor, H. (1998). Suppression of immune responses by CD8 cells. II. Qa-1 on activated B cells stimulates CD8 cell suppression of $\mathrm{T}$ helper 2 responses. J. Immunol. 160, 566-571.

Ochando, J. C., Homma, C., Yang, Y., Hidalgo, A., Garin, A., Tacke, F., Angeli, V., Li, Y., Boros, P., Ding, Y., Jessberger, R., Trinchieri, G., Lira, S. A., Randolph, G. J., and Bromberg, J. S. (2006). Alloantigen-presenting plasmacytoid dendritic cells mediate tolerance to vascularized grafts. Nat. Immunol. 7, 652-662.

Oertel, M., Berr, F., Schroder, S., Schwarz, R., Tannapfel, A., Wenzke, M., Lamesch, P., Hauss, J., and Kohlhaw, K. (2000). Acute rejection of hepatic allografts from HLA-DR13 (Allele DRB1(*)1301)positive donors. Liver Transpl. 6, 728-733.

Oertel, M., Kohlhaw, K., Diepolder, H. M., Schroder, S., Schwarz, R., Tannapfel, A., Mossner, J., Hauss, J., and Berr, F. (2001). Alloreactivity of natural killer cells in allogeneic liver transplantation. Transplantation 72, 116-122.

Onodera, K., Hancock, W. W., Graser, E., Volk, H. D., Lehmann, M., Chandraker, A., Sayegh, M. H., and Kupiec-Weglinski, J. W. (1997). Th2type cytokines in the "infectious" tolerance pathway. Transplant. Proc. 29, 1290-1291.

Opelz, G., and Dohler, B. (2008a). Effect on kidney graft survival of reducing or discontinuing maintenance immunosuppression after the first year posttransplant. Transplantation 86, 371-376.

Opelz, G., and Dohler, B. (2008b). Influence of time of rejection on long-term graft survival in renal transplantation. Transplantation 85, 661-666.

Opelz, G., Wujciak, T., Dohler, B., Scherer, S., and Mytilineos, J. (1999). HLA compatibility and organ transplant survival. Collaborative Transplant Study. Rev. Immunogenet. 1, 334-342.

Owen, R. D., Wood, H. R., Foord, A. G., Sturgeon, P., and Baldwin, L. G. (1954). Evidence for actively acquired tolerance to $\mathrm{Rh}$ antigen.
Proc. Natl. Acad. Sci. U.S.A. 40, 420-424.

Palmer, G., Talabot-Ayer, D., Kaya, G., and Gabay, C. (2007). Type I IL-1 receptor mediates IL-1 and intracellular IL-1 receptor antagonist effects in skin inflammation. J. Invest. Dermatol. 127, 1938-1946.

Pasare, C., and Medzhitov, R. (2005). Toll-like receptors: linking innate and adaptive immunity. $A d v$. Exp. Med. Biol. 560, 11-18.

Patel, H., Smith, R. A., Sacks, S. H. and Zhou, W. (2006). Therapeutic strategy with a membrane-localizing complement regulator to increase the number of usable donor organs after prolonged cold storage. J. Am. Soc. Nephrol. 17, 1102-1111.

Peitsch, M. C., and Tschopp, J. (1991). Assembly of macromolecular pores by immune defense systems. Curr Opin. Cell Biol. 3, 710-716.

Peng, Q., Li, K., Anderson, K., Farrar, C. A., Lu, B., Smith, R. A., Sacks, S. H., and Zhou, W. (2008). Local production and activation of complement up-regulates the allostimulatory function of dendritic cells through C3a-C3aR interaction. Blood 111, 2452-2461.

Peng, Q., Li, K., Patel, H., Sacks, S. H., and Zhou, W. (2006). Dendritic cell synthesis of $\mathrm{C} 3$ is required for full $\mathrm{T}$ cell activation and development of a Th1 phenotype. J. Immunol. 176, 3330-3341.

Piccotti, J. R., Chan, S. Y., Goodman, R. E., Magram, J., Eichwald, E. J., and Bishop, D. K. (1996). IL12 antagonism induces $\mathrm{T}$ helper 2 responses, yet exacerbates cardiac allograft rejection. Evidence against a dominant protective role for $\mathrm{T}$ helper 2 cytokines in alloimmunity. J. Immunol. 157, 1951-1957.

Piccotti, J. R., Chan, S. Y., VanBuskirk, A. M., Eichwald, E. J., and Bishop, D. K. (1997). Are Th2 helper T lymphocytes beneficial, deleterious, or irrelevant in promoting allograft survival? Transplantation 63 619-624.

Porrett, P. M., Yuan, X., LaRosa, D. F., Walsh, P. T., Yang, J., Gao, W., Li, P., Zhang, J., Ansari, J. M., Hancock, W. W., Sayegh, M. H., Koulmanda, M., Strom, T. B., and Turka, L. A. (2008). Mechanisms underlying blockade of allograft acceptance by TLR ligands. J. Immunol. 181, 1692-1699.

Poulin, L. F., Richard, M., Le Moine, A., Kiss, R., McKenzie, A. N., Goldman, M., Renauld, J. C., Van Snick, J., and Braun, M. Y. (2003). Interleukin-9 promotes eosinophilic rejection of mouse heart allografts. Transplantation 76, 572-577.
Pratt, J. R., Basheer, S. A., and Sacks, S. H. (2002). Local synthesis of complement component C3 regulates acute renal transplant rejection. Nat. Med. 8, 582-587.

Raedler, H., and Heeger, P. S. (2010). Complement regulation of $\mathrm{T}$-cell alloimmunity. Curr. Opin. Organ Transplant. 16, 54-60.

Raedler, H., Yang, M., Lalli, P. N., Medof, M. E., and Heeger, P. S. (2009). Primed CD8(+) T-cell responses to allogeneic endothelial cells are controlled by local complement activation. Am. J. Transplant. 9, 1784-1795.

Rao, D. A., Eid, R. E., Qin, L., Yi, T., Kirkiles-Smith, N. C., Tellides, G., and Pober, J. S. (2008). Interleukin (IL)-1 promotes allogeneic T cell intimal infiltration and IL-17 production in a model of human artery rejection. J. Exp. Med. 205, 3145-3158.

Rao, D. A., and Pober, J. S. (2008). Endothelial injury, alarmins, and allograft rejection. Crit. Rev. Immunol. 28, 229-248.

Rao, D. A., Tracey, K. J., and Pober, J. S. (2007). IL-1alpha and IL-1beta are endogenous mediators linking cell injury to the adaptive alloimmune response. J. Immunol. 179, 6536-6546.

Rehli, M. (2002). Of mice and men: species variations of Toll-like receptor expression. Trends Immunol. 23, 375-378.

Rocha, P. N., Plumb, T. J., Crowley, S. D., and Coffman, T. M. (2003). Effector mechanisms in transplant rejection. Immunol. Rev. 196, 51-64.

Rogers, N. J., and Lechler, R. I. (2001). Allorecognition. Am. J. Transplant. 1, 97-102.

Roh, J. D., Sawh-Martinez, R., Brennan, M. P., Jay, S. M., Devine, L., Rao, D. A., Yi, T., Mirensky, T. L., Nalbandian, A., Udelsman, B., Hibino, N., Shinoka, T., Saltzman, W. M., Snyder, E., Kyriakides, T. R., Pober, J. S., and Breuer, C. K. (2010). Tissueengineered vascular grafts transform into mature blood vessels via an inflammation-mediated process of vascular remodeling. Proc. Natl. Acad. Sci. U.S.A. 107, 4669-4674.

Roncarolo, M. G., Levings, M. K., and Traversari, C. (2001). Differentiation of $\mathrm{T}$ regulatory cells by immature dendritic cells. J. Exp. Med. 193, F5-F9.

Roy, S., Barnes, P. F., Garg, A., Wu, S., Cosman, D., and Vankayalapati, R. (2008). NK cells lyse T regulatory cells that expand in response to an intracellular pathogen. J. Immunol. 180, 1729-1736. 
Russell, P. S., Chase, C. M., and Colvin, R. B. (1997). Alloantibodyand $\mathrm{T}$ cell-mediated immunity in the pathogenesis of transplant arteriosclerosis: lack of progression to sclerotic lesions in B celldeficient mice. Transplantation 64 1531-1536.

Sacks, S., Lee, Q., Wong, W., and Zhou, W. (2009). The role of complement in regulating the alloresponse. Curr. Opin. Organ Transplant. 14, 10-15.

Sakaguchi, S., Negishi, H., Asagiri, M., Nakajima, C., Mizutani, T., Takaoka, A., Honda, K., and Taniguchi, T. (2003). Essential role of IRF-3 in lipopolysaccharide-induced interferon-beta gene expression and endotoxin shock. Biochem. Biophys. Res. Commun. 306, 860-866.

Sallusto, F., Mackay, C. R., and Lanzavecchia, A. (2000). The role of chemokine receptors in primary, effector, and memory immune responses. Annu. Rev. Immunol. 18, 593-620.

Sandberg, J. O., Eizirik, D. L., Sandler, S., Tracey, D. E., and Andersson, A. (1993). Treatment with an interleukin-1 receptor antagonist protein prolongs mouse islet allograft survival. Diabetes 42, 1845-1851.

Sanderson, C. J. (1992). Interleukin-5, eosinophils, and disease. Blood 79, 3101-3109.

Sayed, B. A., and Brown, M. A. (2007). Mast cells as modulators of $\mathrm{T}$ cell responses. Immunol. Rev. 217, 53-64.

Sayed, B. A., Christy, A., Quirion, M. R., and Brown, M. A. (2008). The master switch: the role of mast cells in autoimmunity and tolerance. Annu. Rev. Immunol. 26, 705-739.

Sayegh, M. H., and Carpenter, C. B. (1996). Role of indirect allorecognition in allograft rejection. Int. Rev. Immunol. 13, 221-229.

Sayegh, M. H., Watschinger, B., and Carpenter, C. B. (1994). Mechanisms of $T$ cell recognition of alloantigen. The role of peptides. Transplantation 57, 1295-1302.

Schneider, E., Leite-de-Moraes, M., and Dy, M. (2010). Histamine, immune cells and autoimmunity. Adv. Exp. Med. Biol. 709, 81-94.

Shahaf, G., Moser, H., Ozeri, E., Mizrahi, M., Abecassis, A., and Lewis, E. C. (2011). alpha-1-Antitrypsin gene delivery reduces inflammation, increases T-regulatory cell population size and prevents islet allograft rejection. Mol. Med. 17, 1000-1011.
Shen, H., and Goldstein, D. R. (2009). IL-6 and TNF-alpha synergistically inhibit allograft acceptance. J. Am. Soc. Nephrol. 20, 1032-1040.

Shimamoto, A., Pohlman, T. H., Shomura, S., Tarukawa, T., Takao, M., and Shimpo, H. (2006). Toll-like receptor 4 mediates lung ischemiareperfusion injury. Ann. Thorac. Surg. 82, 2017-2023.

Shirwan, H. (1999). Chronic allograft rejection. Do the Th2 cells preferentially induced by indirect alloantigen recognition play a dominant role? Transplantation 68 , 715-726.

Shirwan, H., Mhoyan, A., Yolcu, E. S., Que, X., and Ibrahim, S. (2003). Chronic cardiac allograft rejection in a rat model disparate for one single class I MHC molecule is associated with indirect recognition by CD4(+) T cells. Transpl. Immunol. 11, 179-185.

Simeonovic, C. J., Townsend, M. J., Wilson, J. D., McKenzie, K. U., Ramsay, A. J., Matthaei, K. I., Mann, D. A., and Young, I. G. (1997). Eosinophils are not required for the rejection of neovascularized fetal pig proislet xenografts in mice. J. Immunol. 158, 2490-2499.

Smyth, L. A., Afzali, B., Tsang, J., Lombardi, G., and Lechler, R. I. (2007). Intercellular transfer of MHC and immunological molecules: molecular mechanisms and biological significance. Am. J. Transplant. 7, 1442-1449.

Smyth, L. A., Herrera, O. B., Golshayan, D., Lombardi, G., and Lechler, R. I. (2006). A novel pathway of antigen presentation by dendritic and endothelial cells: implications for allorecognition and infectious diseases. Transplantation 82, S15-S18.

Smyth, M. J., Cretney, E., Takeda, K., Wiltrout, R. H., Sedger, L. M., Kayagaki, N., Yagita, H., and Okumura, K. (2001). Tumor necrosis factor-related apoptosis-inducing ligand (TRAIL) contributes to interferon gamma-dependent natural killer cell protection from tumor metastasis. J. Exp. Med. 193, 661-670.

Steenwinckel, V., Louahed, J., Orabona, C., Huaux, F., Warnier, G., McKenzie, A., Lison, D., Levitt, R., and Renauld, J. C. (2007). IL-13 mediates in vivo IL-9 activities on lung epithelial cells but not on hematopoietic cells. J. Immunol. 178, 3244-3251.

Steinman, R. M., and Cohn, Z. A. (1973). Identification of a novel cell type in peripheral lymphoid organs of mice. Morphology, I., quantitation, tissue distribution. J. Exp. Med. 137, 1142-1162.

Steinman, R. M., Hawiger, D., and Nussenzweig, M. C. (2003) Tolerogenic dendritic cells. Annu. Rev. Immunol. 21, 685-711.

Steinman, R. M., Turley, S., Mellman, I. and Inaba, K. (2000). The induction of tolerance by dendritic cells that have captured apoptotic cells. J. Exp. Med. 191, 411-416.

Steinman, R. M., and Witmer, M. D. (1978). Lymphoid dendritic cells are potent stimulators of the primary mixed leukocyte reaction in mice. Proc. Natl. Acad. Sci. U.S.A. 75, 5132-5136.

Stein-Streilein, J., and Streilein, J. W. (2002). Anterior chamber associated immune deviation (ACAID): regulation, biological relevance, and implications for therapy. Int. Rev. Immunol. 21, 123-152.

Strainic, M. G., Liu, J., Huang, D., An, F., Lalli, P. N., Muqim, N., Shapiro, V. S., Dubyak, G. R., Heeger, P. S., and Medof, M. E. (2008). Locally produced complement fragments C5a and $\mathrm{C} 3$ a provide both costimulatory and survival signals to naive CD4+ $\mathrm{T}$ cells. Immunity 28, 425-435.

Streilein, J. W., Ohta, K., Mo, J. S., and Taylor, A. W. (2002). Ocular immune privilege and the impact of intraocular inflammation. DNA Cell Biol. 21, 453-459.

Suciu-Foca, N., Ciubotariu, R., Itescu, S., Rose, E. A., and Cortesini, R. (1998). Indirect allorecognition of donor HLA-DR peptides in chronic rejection of heart allografts. Transplant. Proc. 30, 3999-4000.

Suciu-Foca, N., Liu, Z., Colovai, A. I., Tugulea, S., Reed, E. F., Mancini, D., Cohen, D. J., Benvenisty, A. I., Benstein, J. A., Hardy, M. A., Schulman, L. L., and Rose, E. A. (1996). Role of indirect allorecognition in chronic rejection of human allografts. Transplant. Proc. 28, 404-405.

Sukkar, M. B., Xie, S., Khorasani, N. M., Kon, O. M., Stanbridge, R., Issa, R., and Chung, K. F. (2006). Toll-like receptor 2, 3, and 4 expression and function in human airway smooth muscle. J. Allergy Clin. Immunol. 118, 641-648.

Surquin, M., Le Moine, A., Flamand, V., Rombaut, K., Demoor, F. X., Salmon, I., Goldman, M., and Abramowicz, D. (2005). IL-4 deficiency prevents eosinophilic rejection and uncovers a role for neutrophils in the rejection of MHC class II disparate skin grafts. Transplantation 80, 1485-1492.

Suzuki, K., Murtuza, B., Smolenski, R. T., Sammut, I. A., Suzuki,
N., Kaneda, Y., and Yacoub, M. H. (2001). Overexpression of interleukin-1 receptor antagonist provides cardioprotection against ischemia-reperfusion injury associated with reduction in apoptosis. Circulation 104, I308-I303.

Suzuki, K., Nakajima, H., Watanabe, N., Kagami, S., Suto, A., Saito, Y., Saito, T., and Iwamoto, I. (2000). Role of common cytokine receptor gamma chain (gamma(c))and Jak3-dependent signaling in the proliferation and survival of murine mast cells. Blood 96, 2172-2180.

Szot, G. L., Zhou, P., Rulifson, I., Wang, J., Guo, Z., Kim, O., Newel, K. A., Thistlethwaite, J. R., Bluestone, J. A., and Alegre, M. L. (2001). Different mechanisms of cardiac allograft rejection in wildtype and CD28deficient mice. Am. J. Transplant. 1, 38-46.

Takeda, K., Hayakawa, Y., Smyth, M. J., Kayagaki, N., Yamaguchi, N., Kakuta, S., Iwakura, Y., Yagita, H., and Okumura, K. (2001). Involvement of tumor necrosis factorrelated apoptosis-inducing ligand in surveillance of tumor metastasis by liver natural killer cells. Nat. Med. 7, 94-100.

Tang, S., Zhou, W., Sheerin, N. S., Vaughan, R. W., and Sacks, S. H. (1999). Contribution of renal secreted complement C3 to the circulating pool in humans. J. Immunol. 162, 4336-4341.

Taylor, D. K., Neujahr, D., and Turka, L. A. (2004). Heterologous immunity and homeostatic proliferation as barriers to tolerance. Curr. Opin. Immunol. 16, 558-564.

Tesar, B. M., Jiang, D., Liang, J., Palmer, S. M., Noble, P. W., and Goldstein, D. R. (2006). The role of hyaluronan degradation products as innate alloimmune agonists. Am. J. Transplant. 6, 2622-2635.

Tesar, B. M., Zhang, J., Li, Q., and Goldstein, D. R. (2004). TH1 immune responses to fully $\mathrm{MHC}$ mismatched allografts are diminished in the absence of MyD88, a toll-like receptor signal adaptor protein. Am. J. Transplant. 4, 1429-1439.

Thomson, A. W. (2002). Designer dendritic cells for transplant tolerance. Transplant. Proc. 34, 2727-2728.

Thornley, T. B., Brehm, M. A., Markees, T. G., Shultz, L. D., Mordes, J. P., Welsh, R. M., Rossini, A. A., and Greiner, D. L. (2006). TLR agonists abrogate costimulation blockade-induced prolongation of skin allografts. J. Immunol. 176, 1561-1570. 
Thornley, T. B., Phillips, N. E., Beaudette-Zlatanova, B. C., Markees, T. G., Bahl, K., Brehm, M. A., Shultz, L. D., Kurt-Jones, E. A., Mordes, J. P., Welsh, R. M., Rossini, A. A., and Greiner, D. L. (2007). Type 1 IFN mediates cross-talk between innate and adaptive immunity that abrogates transplantation tolerance. J. Immunol. 179, 6620-6629.

Tian, J., Avalos, A. M., Mao, S. Y., Chen, B., Senthil, K., Wu, H., Parroche, P., Drabic, S., Golenbock, D., Sirois, C., Hua, J., An, L. L., Audoly, L., La Rosa, G., Bierhaus, A., Naworth, P., Marshak-Rothstein, A., Crow, K. A., Fitzgerald, M. K., Latz, E., Kiener, P. A., and Coyle, A. J. (2007). Tolllike receptor 9-dependent activation by DNA-containing immune complexes is mediated by HMGB1 and RAGE. Nat. Immunol. 8, 487-496.

Tokita, D., Mazariegos, G. V., Zahorchak, A. F., Chien, N., Abe, M., Raimondi, G., and Thomson, A. W. (2008). High PD-L1/CD86 ratio on plasmacytoid dendritic cells correlates with elevated T-regulatory cells in liver transplant tolerance. Transplantation 85, 369-377.

Trapani, J. A., and Smyth, M. J. (2002). Functional significance of the perforin/granzyme cell death pathway. Nat. Rev. Immunol. 2, 735-747.

Tsuboi, N., Yoshikai, Y., Matsuo, S., Kikuchi, T., Iwami, K., Nagai, Y., Takeuchi, O., Akira, S., and Matsuguchi, T. (2002). Roles of toll-like receptors in C-C chemokine production by renal tubular epithelial cells. J. Immunol. 169, 2026-2033.

Turnquist, H. R., Raimondi, G., Zahorchak, A. F., Fischer, R. T., Wang, Z., and Thomson, A. W. (2007). Rapamycin-conditioned dendritic cells are poor stimulators of allogeneic $\mathrm{CD} 4+\mathrm{T}$ cells, but enrich for antigen-specific Foxp3+ T regulatory cells and promote organ transplant tolerance. J. Immunol. 178, 7018-7031.

Uehara, S., Chase, C. M., Colvin, R. B., Russell, P. S., and Madsen, J. C. (2005a). Further evidence that NK cells may contribute to the development of cardiac allograft vasculopathy. Transplant. Proc. 37, 70-71.

Uehara, S., Chase, C. M., Kitchens, W. H., Rose, H. S., Colvin, R. B., Russell, P. S., and Madsen, J. C. (2005b). NK cells can trigger allograft vasculopathy: the role of hybrid resistance in solid organ allografts. J. Immunol. 175, 3424-3430.

Uematsu, S., and Akira, S. (2007). Toll-like receptors and Type I interferons. J. Biol. Chem. 282, 15319-15323.
Unanue, E. R. (1984). Antigenpresenting function of the macrophage. Annu. Rev. Immunol. 2, 395-428.

Unanue, E. R. (2002). Perspective on antigen processing and presentation. Immunol. Rev. 185, 86-102.

Unanue, E. R., and Allen, P. M. (1986). Biochemistry and biology of antigen presentation by macrophages. Cell. Immunol. 99, 3-6.

Valujskikh, A. (2006). The challenge of inhibiting alloreactive T-cell memory. Am. J. Transplant. 6, 647-651.

Valujskikh, A., and Heeger, P. S. (2003). Emerging roles of endothelial cells in transplant rejection. Curr. Opin. Immunol. 15, 493-498.

Valujskikh, A., Pantenburg, B., and Heeger, P. S. (2002). Primed allospecific $T$ cells prevent the effects of costimulatory blockade on prolonged cardiac allograft survival in mice. Am. J. Transplant. 2, 501-509.

van den Berg, T. K., and van der Schoot, C. E. (2008). Innate immune 'self' recognition: a role for CD47-SIRPalpha interactions in hematopoietic stem cell transplantation. Trends Immunol. 29, 203-206.

van der Touw, W., and Bromberg, J. S. (2010). Natural killer cells and the immune response in solid organ transplantation. Am. J. Transplant. 10, 1354-1358.

VanBuskirk, A. M., Wakely, M. E., and Orosz, C. G. (1996). Transfusion of polarized TH2-like cell populations into SCID mouse cardiac allograft recipients results in acute allograft rejection. Transplantation 62, 229-238.

Varol, C., Yona, S., and Jung, S. (2009). Origins and tissue-contextdependent fates of blood monocytes. Immunol. Cell Biol. 87, 30-38.

Vieyra, M. B., and Heeger, P. S. (2010). Novel aspects of complement in kidney injury. Kidney Int. 77, 495-499.

Waaga, A. M., Gasser, M., Kist-van Holthe, J. E., Najafian, N., Muller, A., Vella, J. P., Womer, K. L., Chandraker, A., Khoury, S. J., and Sayegh, M. H. (2001). Regulatory functions of selfrestricted MHC class II allopeptidespecific Th2 clones in vivo. J. Clin. Invest. 107, 909-916.

Waaga, A. M., Murphy, B., Chen, W., Khoury, S. J., and Sayegh, M. H. (1997). Class II MHC allopeptide-specific T-cell clones transfer delayed type hypersensitivity responses in vivo. Transplant. Proc. 29, 1008-1009.

Walker, W. E., Nasr, I. W., Camirand, G., Tesar, B. M., Booth, C. J., and
Goldstein, D. R. (2006). Absence of innate MyD88 signaling promotes inducible allograft acceptance. J. Immunol. 177, 5307-5316.

Wanderer, A. A. (2010). Rationale and timeliness for IL-1beta-targeted therapy to reduce allogeneic organ injury at procurement and to diminish risk of rejection after transplantation. Clin. Transplant. 24, 307-311.

Wang, H., VerHalen, J., Madariaga, M. L., Xiang, S., Wang, S., Lan, P., Oldenborg, P. A., Sykes, M., and Yang, Y. G. (2007). Attenuation of phagocytosis of xenogeneic cells by manipulating CD47. Blood 109, 836-842.

Wang, T., Chen, L., Ahmed, E., Ma, L., Yin, D., Zhou, P., Shen, J., Xu, H., Wang, C. R., Alegre, M. L., and Chong, A. S. (2008). Prevention of allograft tolerance by bacterial infection with Listeria monocytogenes. J. Immunol. 180, 5991-5999.

Weaver, T. A., Charafeddine, A. H., Agarwal, A., Turner, A. P., Russell, M., Leopardi, F. V., Kampen, R. L., Stempora, L., Song, M., Larsen, C. P., and Kirk, A. D. (2009). Alefacept promotes co-stimulation blockade based allograft survival in nonhuman primates. Nat. Med. 15 , 746-749.

Weisman, H. F., Bartow, T., Leppo, M. K., Marsh, H. C., Carson, G. R., Concino, M. F., Boyle, M. P., Roux, K. H., Weisfeldt, M. L., and Fearon, D. T. (1990). Soluble human complement receptor type 1, in vivo inhibitor of complement suppressing postischemic myocardial inflammation and necrosis. Science 249, 146-151.

Wilson, N. S., and Villadangos, J. A. (2004). Lymphoid organ dendritic cells: beyond the Langerhans cells paradigm. Immunol. Cell Biol. 82, 91-98.

Wu, H., Chen, G., Wyburn, K. R., Yin, J. Bertolino, P., Eris, J. M., Alexander, S. I., Sharland, A. F., and Chadban, S. J. (2007a). TLR4 activation mediates kidney ischemia/reperfusion injury. J. Clin. Invest. 117, 2847-2859.

Wu, Y., Welte, T., Michaud, M., and Madri, J. A. (2007b). PECAM1: a multifaceted regulator of megakaryocytopoiesis. Blood 110, 851-859.

Wu, Y., and Madri, J. (2010). Insights into monocyte-driven osteoclastogenesis and its link with hematopoiesis: regulatory roles of PECAM-1 (CD31) and SHP-1. Crit. Rev. Immunol. 30, 423-433.

Yamada, A., Laufer, T. M., Gerth, A. J., Chase, C. M., Colvin, R. B., Russell, P. S., Sayegh, M. H., and Auchincloss, H. Jr. (2003). Further analysis of the T-cell subsets and pathways of murine cardiac allograft rejection. Am. J. Transplant. 3, 23-27.

Yamada, J., Dana, M. R., Zhu, S. N., Alard, P., and Streilein, J. W. (1998). Interleukin 1 receptor antagonist suppresses allosensitization in corneal transplantation. Arch. Ophthalmol. 116, 1351-1357.

Yamada, J., Yoshida, M., Taylor, A. W., and Streilein, J. W. (1999). Mice with Th2-biased immune systems accept orthotopic corneal allografts placed in "high risk" eyes. J. Immunol. 162, 5247-5255.

Yamada, J., Zhu, S. N., Streilein, J. W., and Dana, M. R. (2000). Interleukin1 receptor antagonist therapy and induction of anterior chamberassociated immune deviation-type tolerance after corneal transplantation. Invest. Ophthalmol. Vis. Sci. 41 , 4203-4208.

Yamada, Y., Aoyama, A., Boskovic, S., Nadazdin, O., Benichou, G., Cosimi, A. B., and Kawai, T. (2011). Post-transplant memory $\mathrm{T}$ cells and inflammatory responses inhibit delayed tolerance induction. Am. J. Ther. 11, 28.

Yan, Z. Q., and Hansson, G. K. (2007). Innate immunity, macrophage activation, and atherosclerosis. Immunol. Rev. 219, 187-203.

Yona, S., and Jung, S. (2010). Monocytes: subsets, origins, fates and functions. Curr. Opin. Hematol. 17, 53-59.

Yoshida, O., Akbar, F., Miyake, T., Abe, M., Matsuura, B., Hiasa, Y., and Onji, M. (2008). Impaired dendritic cell functions because of depletion of natural killer cells disrupt antigenspecific immune responses in mice: restoration of adaptive immunity in natural killer-depleted mice by antigen-pulsed dendritic cell. Clin. Exp. Immunol. 152, 174-181.

Zarember, K. A., and Godowski, P. J. (2002). Tissue expression of human Toll-like receptors and differential regulation of Toll-like receptor mRNAs in leukocytes in response to microbes, their products, and cytokines. J. Immunol. 168, 554-561.

Zhou, W., Farrar, C. A., Abe, K., Pratt, J. R., Marsh, J. E., Wang, Y., Stahl, G. L., and Sacks, S. H. (2000). Predominant role for C5b-9 in renal ischemia/reperfusion injury. J. Clin. Invest. 105, 1363-1371.

Zhou, W., Medof, M. E., Heeger, P. S., and Sacks, S. (2007). Graft-derived complement as a mediator of transplant injury. Curr. Opin. Immunol. 19, 569-576. 
Zhou, W., Patel, H., Li, K., Peng, Q., Villiers, M. B., and Sacks, S. H. (2006). Macrophages from C3-deficient mice have impaired potency to stimulate alloreactive $\mathrm{T}$ cells. Blood 107, 2461-2469.

Conflict of Interest Statement: The authors declare that the research was conducted in the absence of any commercial or financial relationships that could be construed as a potential conflict of interest.

Received: 29 December 2011; paper pending published: 09 February 2012; accepted: 22 March 2012; published online: 19 April 2012.
Citation: Benichou G, Tonsho $M$, Tocco G, Nadazdin $O$ and Madsen JC (2012) Innate immunity and resistance to tolerogenesis in allotransplantation. Front. Immun. 3:73. doi: 10.3389/fimmu.2012.00073

This article was submitted to Frontiers in Immunological Tolerance, a specialty of Frontiers in Immunology.
Copyright (c) 2012 Benichou, Tonsho, Tocco, Nadazdin and Madsen. This is an open-access article distributed under the terms of the Creative Commons Attribution Non Commercial License, which permits non-commercial use, distribution, and reproduction in other forums, provided the original authors and source are credited. 